\title{
Ex-Dividend Prices and Investor Trades: Evidence from Taiwan
}

\author{
Hung-Ling Chen \\ Department of Finance \\ College of Business \\ China University of Technology \\ Taipei 116, Taiwan, ROC. \\ Tel: 886-2-22304720 \\ Email: yao1220@cute.edu.tw
}

\author{
Edward H. Chow \\ Department of Finance \\ College of Commerce \\ National Chengchi University \\ Taipei 116, Taiwan, ROC. \\ Tel: 886-2-29393091 ext. 81206 \\ Email:echow@nccu.edu.tw \\ Cheng-Yi Shiu ${ }^{*}$ \\ Department of Finance \\ College of Management \\ National Central University \\ Taoyuan, Taiwan, ROC \\ Email: cshiu@ncu.edu.tw \\ Tel: 886-3-4227151 ext. 66268
}

January 2011

* Corresponding author. We are grateful to the seminar participants at the $23^{\text {th }}$ Australasian Finance and Banking Conference, and the $15^{\text {th }}$ Conference on the Theories and Practices of Securities and Financial Market in Kaohsiung, Taiwan, for the valuable comments provided. 


\title{
Ex-Dividend Prices and Investor Trades: Evidence from Taiwan
}

\begin{abstract}
Based upon an examination of 987 ex-dividend events that took place on the Taiwan Stock Exchange between January 1992 and December 2006, we find that differential taxes are an important factor in terms of their effects on share prices and the behavior of investors around the ex-dividend day. Ex-day price drop ratio increases with the average investor's preference for dividend relative to capital gains. Excess volume around the ex-dividend day is positively correlated with the degree of tax heterogeneity and the gains from dividend-capturing activities, and is negatively associated with arbitrage risk and transaction costs. We also find that wealthy investors sell shares cum-dividend, subsequently reversing to buy shares on the ex-dividend day, whereas less wealthy investors, proprietary traders and corporate shareholders trade in the opposite direction. Overall, our results provide support for the dynamic dividend clientele hypothesis.
\end{abstract}

JEL classification: G35

Keywords: Ex-dividend day; Dividend tax; Dividend clientele 


\section{Introduction}

Does the tax preference of investors for dividends relative to capital gains can explain the ex-dividend day price behavior? Does the investor tax heterogeneity affect the trading volume around the ex-dividend day? Do investors engage in dividend-capturing trades? Such questions have interested researchers over several decades and are central to understanding the behavior of stock price and trading volume around the ex-dividend day, and to understanding the effect of differential taxes on the tax-avoidance trades by different groups of investors. In this paper, we try to answer these questions by examining the effect of investors' tax preference and tax heterogeneity on the ex-day price drop ratio (hereafter PDR), trading volume and investors' trade around the ex-dividend day.

In their dividend clientele model, Elton and Gruber (1970) demonstrate that, because dividend tax rate is generally higher than capital gains tax rate, ex-day PDRs are, on average, less than one. They also find that PDR generally increases with the dividend yield, indicating that investors with lower tax rate prefer high yield stocks, while those in higher tax brackets prefer low yield stocks. Studies such as Poterba and Summers (1984), Barclay (1987), Lasfer (1995), Bell and Jenkinson (2002), Graham, Michaely and Roberts (2003), Elton, Gruber and Blake (2005), and Whitworth and Rao (2010) find evidences consistent with the dividend clientele hypothesis. In contrast, Kalay (1982) suggests that by capturing dividends, short-term arbitrageurs would eliminate the profits between the price drop and dividends on the ex-dividend day. The short-term arbitrage hypothesis predicts that the ex-day return would reflect the transaction costs of short-term traders, and is supported in Lakonishok and Vermaelen (1986) and Karpoff and Walkling (1988). 
More recently, Michaely and Vila (1995) and Michaely, Vila, and Wang (1996) propose the dynamic tax-induced dividend clientele model. They assert that investors trade with one another around the ex-dividend day as a result of the differential valuation of dividends. Investors with tax advantages on their dividends would hold and buy stocks cum-dividend, while investors with tax disadvantages would tend to sell their shares prior to the ex-dividend day and buy shares back on the ex-day. In those tax-induced trades, dividend yields and tax heterogeneity represents the gains from tax arbitrage trades, while risk and transaction costs are friction that could prevent investors from tax arbitrage trades. In equilibrium, ex-day PDR is determined by the average preference of all investors for dividends relative to capital gains, rather than by any single groups of investors. The trading volume around the ex-dividend day is also affected by tax heterogeneity, as well as the dividend yield, risk, and transaction costs.

In this paper, we search direct evidence of dynamic tax-induced dividend clientele by investigating the firm-level price behavior, trading volume, and investors' trade around the ex-dividend day. Based on the dynamic dividend clientele model, a firm whose majority shareholders have greater tax preference for dividends relative to capital gains should have a greater ex-day PDR. Similarly, a firm whose ownership is more dispersed in tax preference for dividends should have greater degree of tax heterogeneity and should have more excess volume around the ex-dividend day. Several studies have provided evidences of dynamic tax-induced dividend clientele. However, due to the limitation of the firm level data for ownership and shareholder's applicable tax rates, past literature does not find the direct association of PDR with average shareholder tax preference, neither does it find the direct relation between excess volume and tax heterogeneity among different groups of 
investors. ${ }^{1}$ For example, Zhang, Farrell and Brown (2008) compare the ex-day PDR and trading volume before and after the Jobs and Growth Tax Relief Reconciliation Act of 2003, which removes the differential taxation between dividends and capital gains for individual investors and leads to raise the tax preference of individual investors for dividends relative to capital gains and mitigate the degree of tax heterogeneity among different groups of investors as a result. They find that ex-day PDR increases and excess volume decreases in the post-Act period. Although they interpret their empirical results to be consistent with the dynamic dividend clientele, they do not provide a direct evidence to support the necessary conditions we discussed earlier.

In a related study, Michaely and Murgia (1995) examine the effect of differential taxes on the ex-day return and volume by looking at the Italian stock market, which has different dividend taxes on two classes of stocks. To explore the association, they calculate the market average tax preference of investors every year using the actual proportional holdings of individuals, corporations, and mutual funds in the universe of Italian market. For savings stock dividends, which are taxed at a fixed rate of 15 percent for all market participants, Michaely and Murgia find that the PDR is almost identical to what the theory predicts. However, for common stock dividends, which are taxed at various rates for different investors, the association between PDR and the market average tax preference for dividends relative to capital gains does not hold. Since they investigate the association at market level rather than at firm level, lack of variation in the observations makes it more

\footnotetext{
${ }^{1}$ The direct association between PDR and the average tax preference of investors for dividends relative to capital gains and the direct relation between excess volume and the tax heterogeneity among different groups of investors are necessary conditions in the empirical test of dynamic tax-induced dividend clientele model as proposed by Michaely and Vila (1995) and Michaely, Vila, and Wang (1996). We discuss the issue in section 2.
} 
difficult to precisely estimate such relationship. Perhaps the association exists at the firm level but it disappears when the average tax preference is calculated using the universe ownership.

In another related paper of interest, Graham and Kumar (2006) find that ex-day PDR is higher for stocks with greater ownership by older investors or lower income. Their evidence is consistent with the dynamic tax-induced dividend clientele model that the investors' tax preferences being impounded into PDR. However, their results are significant for small-cap stocks only, and more importantly, their measure of average tax preferences for dividends relative to capital gains is probably not precise because their US discount brokerage data covers 9,396 retail investors only.

In the examination of the trading volume around the ex-dividend day, Dhaliwal and Li (2006) document a concave relation between the excess volume and institutional ownership. Using the level of institutional ownership as a proxy for tax heterogeneity, they find a low trading volume around the ex-dividend day for stocks with either extremely low or extremely high institutional ownership, which stands for a low degree of tax heterogeneity among investors. However, institutional ownership may not be a good proxy for tax heterogeneity.

Based upon an examination of ex-dividend events in Taiwan, our primary aim in this study is to contribute to the debate on whether differential taxes play important roles with regard to share prices and investor behavior around the ex-dividend day. Specifically, we empirically test the dynamic dividend clientele model proposed by Michaely and Vila (1995) using 987 dividend distribution events in Taiwan during the sample period of 1992-2006, which saw a major 1998 tax reform that altered the relative attractiveness of 
dividends versus capital gains and increased tax heterogeneity.

To overcome the drawback of measures used in the past literature for investors' average tax preference for dividend and tax heterogeneity among investors, in this paper we calculate two firm-level variables. We construct the average tax preference of investors for dividends relative to capital gains for every sample firm each year, using ownership and shareholder's applicable tax rates. We find that the average tax preference variable is very successful in explaining the variations in ex-day PDR. We also construct an additional variable to measure the degree of tax heterogeneity among shareholders for every sample firm each year. The excess trading volume around the ex-dividend day is highly related to the tax heterogeneity variable. Perhaps more importantly, the relation found in our study is stronger than that in Dhaliwal and Li (2006), which can probably be attributed to the fact that our measure of tax heterogeneity is more precise than theirs.

To provide additional convincing evidences to support the dynamic dividend clientele argument, we examine trade imbalance in high-dividend yield stocks for different groups of investors. We find that wealthy individuals tend to sell shares cum-dividend and then reverse to buy shares on the ex-dividend day and for several days thereafter. In contrast, less wealthy investors, proprietary traders and other corporate shareholders tend to be on the buy side before the ex-day, then sell shares that have gone ex-dividend. Our results are consistent with the findings in Koski and Scruggs (1998), Rantapuska (2008) and Felixson and Liljeblom (2008) that investors with tax disadvantages will trade their dividend with those investors who have tax advantages. A noteworthy contribution of our analysis is that the tax-induced trade is stronger in the post-Act period, when the degree of tax heterogeneity is higher. 
Despite its status as an emerging market, Taiwan market is the subject of our study because it has three major advantages. First, the taxation system in Taiwan is less complicated than that in the US. Of considerable importance and interest is the major tax reform of 1998 Income Tax Act (hereafter, the 1998 Act, or Act), which saw the implementation of the imputation tax system. The Act has materially altered the average preference for dividends relative to capital gains, as well as the degree of tax heterogeneity. We can therefore examine the effect of tax preference on share prices and investor behavior around the ex-dividend day by examining the ex-dividend events before and after the Act.

Second, firms in Taiwan pay dividends only once a year, so the problems caused by tiny dividends are not a significant issue in our sample. Third, comprehensive details on the transaction records of all investors on the Taiwan Stock Exchange are available for this study. Thus, we have high-quality data to examine the behavior of investors around the ex-dividend day.

This study provides several important contributions to the literature. We are able to design variables measuring the average tax preference for dividends relative to capital gains and tax heterogeneity among different groups of investors. We provide evidence to show that the average tax preference for dividends relative to capital gains can successfully explain the variation in the ex-day PDR, and that tax heterogeneity is the major determinant of the excess volume around the ex-dividend day. This is in line with several prior studies examining the dynamic dividend clientele model. ${ }^{2}$ However, compared to the prior works, our study goes a step further by constructing average tax preference and tax heterogeneity variables, and finds that these two variables are very effective in explaining

\footnotetext{
2 Examples include Michaely and Murgia (1995), Michaely and Vila (1996), Dhaliwal and Li (2006) and Zhang et al. (2008).
} 
the variations in the ex-day PDR and excess volume.

In addition, while the majority of prior studies examined dividend distributions in the US or other developed markets, we supplement the literature with evidence from an emerging market, where individual investors dominate the market, to demonstrate the effect of differential taxes on share prices and the behavior of investors around the ex-dividend day. Finally, we provide evidence to show that prior to the ex-dividend day, wealthy investors are net sellers, while less wealthy investors, proprietary traders and corporate shareholders are net buyers, and that they change the direction of their trades on the ex-day and thereafter. This phenomenon is more significant in the post-Act period in which the degree of tax heterogeneity is higher, implying that the excess volume around the ex-dividend day is related to tax-induced trades.

The remainder of this paper is organized as follows. A brief introduction to the income tax system in Taiwan is provided in Section 2, followed in Section 3 by the development of our theoretical analysis and testable hypotheses. Section 4 provides a description of the data and the methodology adopted for this study, with the results of the ex-day PDR being presented in Section 5. Section 6 reports the results on trading volume around the ex-dividend day, while Section 7 presents the results on trade imbalance by different investor groups. Finally, the conclusions drawn from this study are presented and summarized in Section 8.

\section{The Income Tax System in Taiwan}

The income tax system in Taiwan comprises of corporate income tax and individual income tax. The corporate income tax is imposed on the profits of all profit-seeking enterprises, including corporations, partnerships, proprietorships and other organizations, 
while the individual income tax is imposed on the consolidated income of all individuals, including both wages and dividends. In this section, we demonstrate the tax burden on dividends for three classes of investors, 'domestic individual investors', 'corporate investors' and 'foreign investors'. 3,4

Prior to the 1998 tax reform, business profits were first taxed at the corporate level rate of 25 percent before net income was distributed to shareholders as dividend income. Domestic individual shareholders receiving dividends were subject to individual income tax according to applicable progressive tax rates, ranging from 6 percent to 40 percent. $^{5}$ In the pre-Act period, an individual was granted a tax exemption on interest and dividend income up to a maximum of NT $\$ 270,000$, while domestic corporate shareholders were also granted an 80 percent exclusion from their dividend income.

Dividends paid to foreign shareholders in the pre-Act period were subject to a withholding tax at the rate of 20 percent or 25 percent if the foreign investors had invested directly from offshore (defined here as non-resident foreign investors). ${ }^{6}$ If the foreign investors set up a branch and made the investment through that branch (defined here as resident foreign investors), then the tax treatment of that branch was the same as that for

\footnotetext{
3 Investors are classified into five groups in this study: 'domestic individual investors', 'foreign investors', 'mutual funds', 'proprietary traders' and 'other corporate investors'. In analyzing the price and volume on the ex-day, mutual funds and proprietary traders are incorporated into the group of 'other corporate investors' since these investors come under the same tax status in the Taiwan stock market.

${ }^{4}$ There is no capital gains tax on marketable securities for all investors in our sample period. It is impossible that investors would trade on the 'capital loss' around the ex-dividend day to offset their capital gains tax.

5 There are five brackets of individual income tax. After exemptions and deductions, the lowest rate of 6 percent is applied to ordinary income of NT\$ $0-370,000$, followed by marginal tax rates of 13 percent for NT\$370,001-990,000, 21 percent for NT\$990,001-1,980,000 and 30 percent for NT\$1,980,001-3,720,000. The highest tax rate, 40 percent, is applied to income above NT\$3,720,001.

${ }^{6}$ For foreign investors approved by the Investment Commission of the Ministry of Economic Affairs to conduct business in Taiwan (resident foreign investors), the withholding tax rate is 20 percent, while the withholding tax rate for non-government approved foreign investors (non-resident foreign investors) is 25 percent. Since the majority of foreign investors undertaking investment during our sample period were approved by government, we use the withholding tax rate of 20 percent as the basis for our analysis.
} 
domestic corporate shareholders.

Taiwan enacted its tax reform on 1 January 1998, which introduced an integrated system for dividend taxation. This would allow shareholders an imputation credit for business income tax against the individual income tax liability on dividends received. An additional 10 percent business income surtax is levied on undistributed earnings.

Under the new tax system, companies should keep an 'Imputation Credit Account' to keep track of the tax paid as well as the imputation tax credits allocated to shareholders. When the earnings are distributed, the company can calculate the imputation tax credit available to its shareholders and notify them accordingly. Given that the dividends distributed in 1999 represent the first occurrence of the distribution of business income earned in 1998, the dividend taxation effective under the 1998 Act applies to those dividends received after 1 January $1999 .^{7}$

Upon receiving their dividends, individual shareholders should include the imputation tax credit in the net dividend received as their gross dividend; that is, the gross dividend consists of the net dividend received plus the imputation tax credit. The gross dividend is included in the consolidated income of shareholders as the taxable base of their income tax. Then the individual shareholders' income tax liability can be offset by the imputation credit received. There are no longer any deductions or exemptions for individual shareholders on dividend income.

Under the new tax system, shareholders who are corporations (henceforth corporate shareholders) are regarded as a pass through entity. Dividend distributed to corporate shareholders is not subject to corporate income taxes, neither can the imputation tax credit be credited against the corporate income tax liability. But the imputation tax credit can be

\footnotetext{
${ }^{7}$ Corporations in Taiwan distribute dividends only once a year.
} 
passed on to individual shareholders of corporate shareholders. Therefore, dividend tax rates and imputation tax credits do not affect the after-tax value of dividends of corporate shareholders.

The 1998 Act did not substantially alter the tax liability of non-resident foreign shareholders. Dividends paid to non-resident shareholders are still subject to a withholding tax at the same rate as before. Although the imputation tax credit is not allocated to non-resident foreign shareholders, the 10 percent surtax which is levied at the corporate level is allowed to offset the withholding tax of non-resident foreign shareholders.

The taxation levels on dividends received by individual investors, domestic corporate investors and foreign investors, in the periods before and after the 1998 Act, are reported in Tables 1, along with the calculations of the imputation tax credits. For simplicity, we assume that the firm distributes all of its net income to shareholders, that it does not retain any earnings, and that the foreign investors are non-resident. So a firm has pre-tax earnings per share of $\frac{1}{1-t_{c}} D$, and net income of $D$ after paying corporate income tax $\frac{t_{c}}{1-t_{c}} D$, where $D$ is the dividend amount, and $t_{\mathrm{c}}$ is the corporate tax rate.

$<$ Tables 1 is inserted about here $>$

In terms of the income tax system in Taiwan, we conclude that there are four features especially relevant to this study: (i) there are no capital gains taxes for all types of investors; (ii) dividends paid in 1999 and thereafter are subject to the imputation tax system; (iii) corporate shareholders have an 80 percent exclusion (up to 1998) or full exclusion (from 1999 onward) of income tax on the dividends received; and (iv) imputation tax credits are not applied to foreign non-resident shareholders, who are subject to a withholding tax at the rate of either 20 or 25 percent. 


\section{Theoretical Analysis and Hypothesis Development}

In this section, we analyze the ways in which the tax structure in Taiwan affects the relative valuation of dividends and capital gains before and after the 1998 Act, as well as the consequent share prices and trading volume around the ex-dividend day. We develop several testable hypotheses for our analysis.

\subsection{Relative Valuation of Dividends to Capital Gains}

We begin by analyzing the tax structure in the pre-Act period. The relative valuation of dividends relative to capital gains for each investor is determined by their tax rate. Let $\alpha$ ${ }^{j}$ be the tax-induced preference for dividends relative to capital gains (the value of one dollar of dividends for each dollar of capital gains) for investor $j$. Given that capital gains tax plays no role in our study, we can also interpret $\alpha^{j}$ as the after-tax value of one dollar of dividends. Thus, the tax preference for dividends in the pre-Act period, $\alpha^{j, p r e}$, can be expressed as:

$$
\alpha^{j, p r e}=\frac{1-t_{d}^{j}}{1-t_{g}^{j}}=1-t_{d}^{j}
$$

where $t_{d}^{j}$ is the marginal tax rate on dividend income for investor $j$, and $t_{g}^{j}$ is the marginal tax rate on capital gains (which is equal to zero because there are no capital gains taxes in our sample period).

Based on the analysis in the Panel B of Table 1, we assume that a firm distributes dividend of one dollar to shareholders in the pre- and post-Act period, respectively. We analyze the tax preference of dividends for wealthy individuals (with a marginal tax rate of 40 percent), less wealthy individuals (6 percent), domestic corporate shareholders, and foreigners, respectively. The analysis is reported in the Panel C of Table 1. 
First, in the pre-Act period, the tax preference for dividends is 0.60 for wealthy individuals with a marginal tax rate of 40 percent. This preference increases to 0.94 for less wealthy individual shareholders (in the 6 percent income tax bracket) in the same period, while the tax preference is 0.95 for corporate shareholders and 0.80 for foreign investors.

Next, we consider taxation level in the post-Act period. Since domestic investors are allocated imputation tax credits at the rate of $t_{c}$, a one-dollar dividend distribution for a domestic investor represents $1 /\left(1-t_{c}\right)$ dollar of pre-tax income. For domestic investor $j$, the tax-induced preference for dividends after considering the imputation tax credits becomes:

$$
\alpha^{j, p o s t}=\frac{1-t_{d}^{j}}{1-t_{c}}
$$

As shown in the Panel $\mathrm{C}$ of Table 1, when holding a stock which has a tax credit of 25 percent, an individual shareholder with a marginal tax rate of 6 percent has a tax preference for dividends of 1.2533; thus, the after-tax value of a one-dollar dividend has been dramatically increased (from 0.94) by the imputation tax system. Similarly, a wealthy shareholder in the 40 percent income tax bracket has a tax preference of 0.80 , a corporate shareholder has a preference of 1.00 , and a foreign investor has a preference of 0.80 . These figures demonstrate that the valuation of dividends relative to capital gains has been raised in the post-Act period. Furthermore, the range between the highest tax preference and the lowest preference, which is 0.4533 in the post-Act period, is higher than the range of 0.35 in the pre-Act period, indicating that the degree of tax heterogeneity has been increased by the 1998 Act.

The tax preference of domestic investors for dividends is also affected by the rate of imputation credits. For example, when holding a stock with a tax credit of 10 percent, the tax preference of dividend for wealthy individuals is 0.6666 , and is 1.0444 for less wealthy 
individual investors.

\subsection{Testable Hypotheses}

In their pioneering work on price behavior on the ex-dividend day, Elton and Gruber (1970) demonstrate that the ex-day PDR reflects the relative value of dividends versus capital gains:

$$
P D R=\frac{P_{c u m}-P_{e x}}{D}=\frac{1-t_{d}}{1-t_{g}}
$$

where $P_{\text {cum }}$ is the cum-dividend day price, $P_{e x}$ is the ex-dividend day price, $D$ is the dividend amount, and $t_{d}\left(t_{g}\right)$ is the dividend tax rate (capital gains tax rate).

In their extension of the work of Elton and Gruber (1970), Michaely and Vila (1995) develop a dynamic model where the ex-day PDR is a function of the average tax preference of all traders for dividends relative to capital gains, risk tolerance, and the arbitrage risk of the stocks that will go ex-dividend:

$$
E(P D R)=\frac{P_{c u m}-E\left(P_{e x} \mid I_{c u m}\right)}{D}=\bar{\alpha}-\frac{X}{K \cdot D} \cdot \sigma_{e}^{2}=\bar{\alpha}-\frac{v}{D / P}
$$

where $E\left(P_{e x} \mid I_{\text {cum }}\right)$ is the expected ex-dividend price given the information set on the cum-dividend day; $\bar{\alpha}$ is the average tax preference of all investors for dividends relative to capital gains weighted by their risk tolerance; $K$ is the aggregate risk tolerance; $X$ is the

aggregate demand for shares; $\sigma_{e}{ }^{2}$ is the uncertainty on the ex-dividend day; $v$ is a risk premium; and $D / P$ is the dividend yield.

From Equation (4), the first variable of interest to this study, and perhaps the most important variable, is $\bar{\alpha}$, the average tax preference of all investors for dividends relative to capital gains, weighted by their risk tolerance. The expected PDR is determined by $\bar{\alpha}$; 
that is, an increase in $\bar{\alpha}$ will lead to an identical amount of increase in expected ex-day PDR. According to the Michaely and Vila (1995) model, the average tax preference of all investors for dividends for each firm in sample year is defined as:

$$
\bar{\alpha}_{i, t}=\sum_{j=1}^{N} w_{t}^{j} \cdot \alpha_{t}^{j}
$$

where $\bar{\alpha}_{i, t}$ is the average tax preference of all investors for dividends for firm $i$ in year $t ; w$ ${ }_{t}^{j}$ is the relative weight of investor $j$ for this firm in year $t ; \alpha_{t}^{j}$ is the tax-induced preference for dividends relative to capital gains for investor $j$ in year $t$, and $N$ is the total number of shareholders in this stock.

Our earlier discussion shows that virtually all investor groups have a higher tax preference for dividends in the post-Act period than in the pre-Act period, with foreign investors being the only exception, since they demonstrate identical tax preferences in the pre- and post-Act periods. This suggests that the average tax preference of all investors for dividends is higher in the post-Act period than in the pre-Act period; that is, $\bar{\alpha}^{\text {post }}>\bar{\alpha}^{\text {pre }}$, which leads to the first of our hypotheses:

Hypothesis 1a: In the post-1998 Act period, there will be an increase in the expected PDR on the ex-dividend day.

In addition to the average tax preference of all investors for dividends in the pre- and post-Act period, we also expect to find that for every sample year, the firm level of $\bar{\alpha}$ (the time-series and cross-sectional value of $\bar{\alpha}$ ) will have a positive association with the PDR. Hypothesis 1b: $\quad$ There will be an increase in the expected PDR with $\bar{\alpha}$, the average after-tax value of $\$ 1.00$ of dividends.

Other factors which can affect the PDR are the dividend yield and arbitrage risk. The 
'dividend clientele' theory, proposed by Elton and Gruber (1970), predicts that investors in the high (low) tax brackets tend to hold low (high) dividend-paying stocks, which implies that the PDR should be an increasing function of dividend yield. Equation (4) confirms that the PDR and dividend yield have the same direction; that is, $\partial P D R / \partial(D / P)>0$. Furthermore, Equation (4) also indicates that the PDR is a decreasing function of arbitrage risk; that is, $\partial P D R / \partial \sigma_{\varepsilon}^{2}<0$. On the ex-dividend day, the greater the shocks on the ex-dividend stock relative to the market risk-bearing capacity, then the lower the expected PDR.

Hypothesis 2: $\quad$ The expected PDR will have a positive correlation with the dividend yield.

Hypothesis 3: $\quad$ The expected PDR will have a negative correlation with risk.

The dynamic dividend clientele model of Michaely and Vila (1995) predicts substantial excess volume around the ex-dividend day, with such excess volume being caused by tax-induced trading resulting from the differential valuations of dividends versus capital gains among the different market participants. The excess volume around the ex-dividend day is determined in the Michaely and Vila (1995) model by the following equation:

$$
V_{e}=\frac{1}{2} D\left\{\sum_{j=1}^{N} \frac{k^{j}}{\sigma_{e}^{2}}\left|\alpha^{j}-\bar{\alpha}\right|\right\}
$$

where $D$ is the dividend amount per share; $k^{j}$ is the risk tolerance of investor $j ; \sigma_{e}{ }^{2}$ is the shock to the stock on the ex-dividend day; and $N$ is the total number of shareholders in the stock. Equation (6) suggests that excess volume is a function of investor tax heterogeneity, 
the amount of dividend and the risk of the stock.

If the tax-induced average preference of all investors for dividends relative to capital gains is found to be homogeneous; that is, if $\alpha^{j}=\bar{\alpha}$ for all $j$ investors, then no excess volume would be discernible around the ex-dividend days, regardless of whether the dividends were to provide either a tax advantage (as in the case where $\alpha^{j}=\bar{\alpha}>1$ ) or a tax disadvantage (as in the case where $\alpha^{j}=\bar{\alpha}<1$ ) for all types of investors. However, if the difference between the various groups of investors with regard to the tax rates on their dividends is sufficiently large, then gains to trading may arise among such investors, and as such, those investors receiving dividends with tax advantages would have incentives to buy shares cum-dividend from those with dividend tax disadvantages. This difference in the tax-induced preference for dividends would clearly result in excess volume around the ex-dividend days.

In order to measure the degree of tax heterogeneity across the various groups of investors, we follow the Michaely and Vila (1996) approach to construct a tax heterogeneity variable for each firm in the sample period:

$$
\text { TAXHET }_{i, t}=\sum_{j=1}^{N} w_{t}^{j} \cdot\left|\alpha^{j}-\bar{\alpha}\right|,
$$

where TAXHET is the tax heterogeneity measure variable. A higher value of TAXHET indicates a higher degree of tax heterogeneity among different classes of investors with different tax status.

Our earlier analysis reveals that the degree of heterogeneity among investors with regard to the tax preference for dividends is higher in the post-Act period than in the pre-Act period; that is, TAXHET ${ }^{\text {post }}>$ TAXHET ${ }^{\text {pre }}$. This indicates that excess volume 
around the ex-dividend days would be higher in the post-Act period than in the pre-Act period.

Hypothesis 4a: $\quad$ An increase in excess trading volume around the ex-dividend day will be discernible after the 1998 Act.

The dispersion of tax heterogeneity can also be applied to the cross-sectional variation in excess volume. We expect to find that those firms with a high (low) degree of heterogeneity in their tax preference for dividends will experience high (low) excess volume around the ex-dividend days.

Hypothesis 4b: $\quad$ All other factors held constant, excess trading volume will increase around the ex-dividend day with the TAXHET.

Michaely and Vila (1995, 1996) and Michaely et al. (1996) argue that with an increase in the dividend yield, there will be a corresponding increase in the gains from dividend-capturing trading; this suggests that excess volume on the ex-dividend day should be increasing with dividend yield. On the other hand, however, Michaely and Vila (1995, 1996) and Michaely et al. (1996) also demonstrate that uncertainty discourages tax arbitrage activities around the ex-dividend day; thus, excess volume should be decreasing with arbitrage risk. They also argue that high transaction costs may erode trading profits, indicating that excess volume is likely to be lower when investors are faced with higher transaction costs.

Hypothesis 5: $\quad$ Excess volume around the ex-dividend day will have a positive correlation with the dividend yield and a negative correlation with the level of arbitrage risk and transaction costs. 
Investors with differing preferences for dividends will tend to trade with each other around the ex-dividend day. As shown in the Panel $\mathrm{C}$ of Table 1, less wealthy individuals and corporate shareholders have higher after-tax valuation of dividends than wealthy individual investors. Therefore, domestic corporate shareholders and less wealthy individual investors will tend to acquire stocks cum-dividend and sell stocks ex-dividend; on the other hand, wealthy individual investors are more likely to sell stocks before the ex-dividend day in order to avoid the tax disadvantage of the dividends.

The 1998 Act improves the after-tax valuation of dividends for all domestic shareholder categories. If the average tax preference of all investors for dividends is impounded into the ex-day PDR, the buy-sell imbalance is expected to be more pronounced in the post-Act period because the 1998 Act increases the degree of tax heterogeneity among different groups of investors.

Hypothesis 6: $\quad$ Less wealthy domestic individual investors and domestic corporate shareholders will be net buyers for stocks cum-dividend, and wealthy individual investors will be net stock sellers prior to the ex-dividend day.

\section{Data and Methodology}

Our sample period for the analysis of ex-dividend day prices and trading activities runs from the beginning of 1992 to the end of 2006. All of the data for this study are obtained from two databases maintained by the Taiwan Economic Journal (TEJ, an important data house in Taiwan); dividend distributions and ex-dividend dates are taken from the TEJ Company database (DB), while daily price and trading volume are taken 
from the TEJ Equity DB. We also acquire a comprehensively detailed intraday dataset from the Taiwan Stock Exchange, which consists of trade price and quantity, along with the identity of all traders.

\subsection{Sample}

The following sample selection criteria are applied to restrict our sample: (i) Firms must have been listed on the Taiwan Stock Exchange for more than three months in order to give all classes of investors plenty of time to make their investment decisions; OTC firms are not included in our analysis because their intraday data are unavailable; (ii) Firms must have at least 60 days of daily trading volume and return data in the estimation period $(-45,-6)$ and $(6,45)$, and have daily trading volume and opening and closing price data in the $(-5,5)$ window; (iii) Only the cash dividends of common stocks are included in our sample; thus, the cash dividends of REITs, mutual funds and preferred stocks are excluded from the sample, as are the stock dividends of common stocks, essentially because of their different characteristics; ${ }^{8}$ (iv) Firms with other material events in the $(-5,5)$ window are deleted from our analysis in order to avoid interference by uncorrelated events; (v) Tiny dividends will lead to large variations in PDR which will create a potential heteroskedasticity problem when performing statistical analysis on PDR; to mitigate this problem, we exclude all stocks with dividends of less than $50 \mathrm{NT}$ cents per share.

The application of the above filters produces a sample of 987 ex-dividend events for our analyses of price, trading volume and buy-sell imbalance by different groups of

\footnotetext{
${ }^{8}$ In a related study, Hu and Tseng (2006) use the same dataset as ours but they examine a sample of 111 stock dividends for firms in Taiwan stock market in 1999. Because a large proportion of stock dividends are not subject to dividend tax, and other non-tax factors are related to stock dividends, they conclude that the tax is neither a necessary condition nor an important factor for the ex-day PDR for stock dividends. In order to have a clean sample, we examine the sample of cash dividends.
} 
investors around the ex-dividend day. Because ownership data is unavailable for 53 of the dividend-paying events, they are removed from tests involving the average tax preference for dividends and tax heterogeneity. Table 2 presents the total number of dividend distributions in the sample, as well as the descriptive statistic of the dividend amount for the sample years from 1992 to 2006.

$<$ Table 2 is inserted about here $>$

Of the total of 987 dividend distribution events, 351 of the events occurred in the pre-Act period (from 1992 to 1998), with the remaining 636 ex-dividend events occurring in the post-Act period (from 1999 to 2006). The mean (median) dividend yield is found to be 2.17 percent (1.92 percent) in the pre-Act period, and 5.80 percent (5.62 percent) in the post-Act period.

\subsection{Measurement of the Price Drop Ratio and Excess Trading Volume}

We consider three measures of the ex-day PDR on the ex-dividend day. Graham et al. (2003) find that most of the ex-dividend price adjustment occurs from the close to the open; therefore, our first measure (PDR1) focuses on the calculation of the short-term price change from the close to the open:

$$
P D R 1=\frac{P_{c u m}^{\text {close }}-P_{e x}^{o p e n}}{D}
$$

where $P_{\text {cum }}^{\text {close }}$ is the closing price of the cum-dividend day, and $P_{e x}^{\text {open }}$ is the opening price of the ex-dividend day.

Since several studies provide empirical analysis of the ex-dividend day using the closing price, we also employ the raw closing price and market-adjusted closing price to calculate the second and third measures (PDR2 and $P D R 3)$ : 


$$
\begin{aligned}
P D R 2 & =\frac{P_{\text {cum }}^{\text {close }}-P_{e x}^{\text {close }}}{D} \\
P D R 3 & =\frac{P_{\text {cum }}^{\text {close }}-\frac{P_{e x}^{\text {close }}}{1+E(R)}}{D}
\end{aligned}
$$

where $P_{e x}^{\text {close }}$ is the closing price on the ex-dividend day, and $E(R)$ is the ex-dividend day expected return, which is calculated as:

$$
E(R)=\hat{\alpha}+\hat{\beta} \cdot R_{m}
$$

where $R m$ is the market return on the ex-day, $\hat{\alpha}$ and $\hat{\beta}$ are estimated from market model using daily return in the estimation period.

In order to calculate excess trading volume, we must first define what constitutes 'normal' trading volume. Similar to Michaely and Vila (1995), Graham et al. (2003) and Zhang et al. (2008), we measure normal trading volume by the average daily turnover in the estimation period:

$$
N V_{i}=\frac{1}{80} \sum_{t} T O_{i, t}, t \in(-45,-6) \cup(6,45)
$$

where $N V_{i}$ is the normal daily volume for the stock in the ex-dividend event, $i$; and $T O_{i, t}$ is the daily turnover rate for the stock on day $t$ of the estimation period.

The excess volume in the $(-5,5)$ event window is calculated as the actual daily turnover of the stock relative to the normal daily volume, minus 1 :

$$
E X V O L_{i, t}=\frac{T O_{i, t}}{N V_{i}}-1, \quad t \in(-5,5)
$$

where $E X V O L_{i, t}$ is the excess volume of stock $i$ on day $t$ of the event window.

\subsection{Firm Characteristic Variables}

The average tax preference of all investors for dividends relative to capital gains, $\bar{\alpha}$, 
is the essential determinant of the PDR. However, despite the importance of $\bar{\alpha}$ being emphasized in the Michaely and Vila (1995) model, it is impossible to precisely calculate this variable due to the data limitation on the cross-sectional variation in tax rates across shareholders, as well as their actual risk tolerance.

We can, however, deal with this problem by estimating the year-end value of $\bar{\alpha}$ in Equation (5) for every ex-dividend firm in our sample period. First, we assume that all investors have identical risk tolerance, and then obtain details on ownership at the end of the previous year for all shareholdings by domestic individual investors, domestic corporations and foreign investors using data from the Source of Capital of Listed Companies for the years 1991 to 2005. The Analysis of Investment by Domestic Individuals on Listed Companies also provides information on the total number of domestic individual shareholders for each firm at the end of each year under 14 different shareholding brackets. Thus, the applicable marginal tax rate of all individual investors can be estimated based upon their total shareholdings.

Individual investors are categorized into five tax brackets according to their shareholding range and tax rate; these are $0-10,000$ (6 percent), 10,001-50,000 (13 percent), 50,001-200,000 (21 percent), 200,001-400,000 (30 percent) and 400,001 and above (40 percent). ${ }^{9}$ We similarly construct the heterogeneity variable TAXHET in Equation (7) for each firm in the sample period. The availability of the time series and cross-sectional data of $\bar{\alpha}$ and TAXHET then enables us to directly test the prediction of the Michaely and Vila (1995) model, as expressed in Equations (4), (5) and (7), as well as the testable hypotheses.

Market capitalization, arbitrage risk and transaction costs are also important variables

\footnotetext{
${ }^{9}$ The classifications used in this study for the ownership-based tax proxy are quite similar to the method employed by Lee, Liu, Roll and Subrahmanyam (2006). We also use other criteria to classify tax rates, and find that the empirical results are qualitatively unchanged.
} 
for our PDR and trading volume analyses. Market capitalization is calculated as the common stock shares outstanding times the closing price of the stock on the last cum-dividend day. We use three distinct risk measures (volatility, systematic risk and idiosyncratic risk); volatility is calculated as the standard deviation of the daily return of the stock in the estimation period scaled by the standard deviation of the market daily return; beta is calculated from the market model using daily returns in the estimation period; and idiosyncratic risk is the standard deviation of the residual term from the regression of beta, scaled by the standard deviation of the market daily return.

Since the Taiwan stock market is based upon an order-driven mechanism with no designated market makers, the bid-ask spread does not necessarily reflect the transaction costs of investors. In this study, we modify the Amihud (2002) illiquidity ratio as a proxy for transaction costs. The illiquidity ratio for the ex-dividend event $i$ is:

$$
\text { ILLI }_{i}=\frac{1}{80} \sum_{t} 1000 \cdot \frac{\left|R_{t}\right|}{\text { Volume }_{t}}, t \in(-45,-6) \cup(6,45)
$$

where $I L L I Q_{i}$ is the illiquidity ratio for the ex-dividend event $i$; $R_{t}$ is the stock return on day $t$; and Volume ${ }_{i}$ is the dollar volume on day $t$.

The illiquidity ratio measures the daily price response which is associated with a one-dollar volume trade. Where stocks have a higher illiquidity ratio, this indicates that investors will have a greater price impact when they place fixed dollar amounts of orders on these stocks. A large price impact hinders the dividend-capturing activities of investors on the ex-dividend day.

\subsection{Summary Statistics}

Table 3 provides the descriptive statistics on the firm characteristics and ownership of 
our sample stocks. As shown in Panel A, the mean market capitalization is NT $\$ 33,551$ millions (median NT\$7,808), which is approximately equal to US\$1,118 million (US\$ 260 million). The mean daily turnover is 0.637 percent (median 0.350 percent), implying an annual turnover rate of 172 percent (median 94 percent) for our sample of ex-dividend stocks. The sample stocks have an average illiquidity ratio of 5.20 percent (median 0.610 percent), and average daily volatility of 1.56 times the market volatility (median 1.47 times). As regards the idiosyncratic risk, the sample stocks have an average risk of 1.32 times the market risk (median 1.18 times). The mean beta is 0.74 (median 0.75 ), indicating that our sample stocks have lower systematic risk than the market aggregate.

$<$ Table 3 is inserted about here $>$

Panel B of Table 3 presents details on stock ownership, revealing that individual investors represent the majority for all of our sample stocks, accounting for 53.62 percent of all of the shares outstanding. This is consistent with the general findings of individual investors dominating the Taiwan stock market. Corporate investors hold, on average, 30.98 percent of the shares in our sample stocks, while foreign investors hold 10.90 percent. $^{10}$ Based upon our rules for categorizing the individual investors into five tax brackets, the mean ownership of investors in the 6 percent income tax rate bracket is 17.06 percent, while the mean ownership in the 40 percent bracket is 13.73 percent.

The summary statistics of $\bar{\alpha}$ and TAXHET for our dividend distribution sample are reported in Panel $\mathrm{C}$ of Table 3, which shows that the mean $\bar{\alpha}$ across the sample stocks is 0.930 (median 0.909 ) with a range of 0.670 to 1.385 . The mean TAXHET is 0.148 (median 0.127 ), with a range of 0.018 to 0.538 . These descriptive statistics indicate that there are

\footnotetext{
${ }^{10}$ The sum of ownership by corporations, foreign investors and individual investors is less than 100 percent; this is because state-owned shareholdings are not considered in our analysis.
} 
wide variations in $\bar{\alpha}$ and TAXHET among our ex-dividend events.

\section{Price Drop Ratio Analysis}

In this section, we examine whether the ex-day PDRs in pre-Act period are different from those in the post-Act period. Details of the difference test for the PDR are presented in Table 4, with Panel A reporting the results of $P D R 1$ (measured by the opening price on the ex-dividend day), Panel B reporting the results of $P D R 2$ (measured by the closing price on the ex-dividend day) and Panel $\mathrm{C}$ reporting the results of PDR3 (calculated using the market-adjusted closing price on the ex-dividend day).

$<$ Table 4 is inserted about here $>$

As shown in Panel A, in the pre-Act period, the average PDR 1 is 0.247 (median 0.400 ), while in the post-Act period, the average $P D R 1$ is 0.868 (median 0.867); it is, therefore, clear that the $P D R 1$ is significantly higher in the post-Act period than in the pre-Act period, with a mean difference of $0.621(t$-statistic $=7.92)$ and a median difference of $0.467(z$-statistic $=15.32)$. Similarly, the results in Panels B and C all suggest that the $P D R$ is significantly increased in the post-Act period.

The results in Table 4 provide overall support for Hypothesis 1a, which predicts an increase in $P D R$ in the post-Act period, which has increased the average tax preference of all investors for dividends. This finding is consistent with the evidence in Zhang et al. (2008) that PDR significantly increases after the 2003 Act, which also increases the after-tax value of dividends for individual investors.

Although our empirical results indicate that the taxation of dividends has a substantial effect on the ex-day PDR, we cannot completely rule out other explanations that are otherwise unrelated to the tax-based theory. First, although the interpretation of the PDR is 
intuitive, essentially because it reflects the market valuation of the after-tax value of a dollar of dividends, the test statistic on the PDR suffers from the problem of heteroskedasticity, as noted by Eades, Hess and Kim (1984). We solve this problem by using ex-day returns to perform statistical analysis.

Second, as regards the case where the PDR is found to be less than 1, Bali and Hite (1998) relate this to tick-size, whereas Frank and Jagannathan (1998) relate it to the bid-ask bounce. We must therefore examine whether our results can be attributed to either of these microstructure explanations.

Finally, the statistics in Table 1 reveal that the dividend yield of the stocks is significantly higher in the post-Act period than in the pre-Act period; thus, it is also likely that the high $P D R$ in the post-Act period may be related to other factors, such as dividend yield, risk or firm size, as opposed to tax differentials. We therefore address this issue using a regression analysis which controls for these other factors.

\subsection{Returns on the Ex-dividend Day}

We calculate the returns on the ex-dividend day as follows:

$$
\begin{gathered}
R E T 1=\frac{P_{e x}^{\text {open }}+D-P_{\text {cum }}^{\text {close }}}{P_{\text {cum }}^{\text {close }}} \\
R E T 2=\frac{P_{e x}^{\text {close }}+D-P_{\text {cum }}^{\text {close }}}{P_{\text {cum }}^{\text {close }}} \\
R E T 3=\frac{P_{e x}^{\text {close }}+D-P_{\text {cum }}^{\text {close }}}{P_{\text {cum }}^{\text {close }}}-E(R)
\end{gathered}
$$

where $R E T 1, R E T 2$ and $R E T 3$ are the respective returns using opening price, closing price and adjusted return on the ex-dividend days, corresponding to the measures of the price drop ratio $(P D R 1, P D R 2$ and $P D R 3)$.

The return on the ex-dividend day is found to be positive when the PDR is less than 1 . 
Our theoretical analysis predicts that the ex-day PDRs should be less than 1 both in the preand post-Act periods, and they should be higher in the post-Act period. This implies that the returns on ex-dividend days will be positive both in the pre- and post-Act periods, whereas they will be lower in the post-Act period.

We find that the mean RET1 is 1.242 percent in the pre-Act period, and 0.697 percent in the post-Act period, a difference of 0.545 percent $(t$-statistic $=5.10)$. Similarly, the mean RET2 (RET3) is 0.735 percent $(0.771$ percent) in the pre-Act period, and 0.313 percent ( 0.222 percent) in the post-Act period; both differences are statistically and economically significant (respectively 0.422 percent and 0.548 percent, with $t$-statistics of 2.81 and $3.96)$.

The evidence on returns on ex-dividend days indicates that our results on PDR are not materially changed. One point worth reiterating is that in order to mitigate the problem of heteroskedasticity caused by tiny dividends, we restrict our sample to those ex-dividend events involving dividends of $50 \mathrm{NT}$ cents or more.

\subsection{Market Microstructure Explanation}

Our empirical results on PDR are unrelated to market microstructure explanations, such as the bid-ask spread and the tick-size, for three reasons. First, events of tiny dividends have been deleted from our analysis of the PDR; therefore, the influence of tick-size or bid-ask bounce on the PDR is limited for our clean sample.

Second, the measures of PDR in the pre-Act period are significantly less than 1; therefore, our empirical results are again unrelated to market-microstructure explanations. Third, since the Taiwan Stock Exchange reduced price discreteness in March 2005, we directly test the issue by comparing the PDR measures both before and after this reduction 
in price discreteness. ${ }^{11}$ If our PDR results are affected by market-microstructure issues, we would observe the PDR measures being closer to 1 after the reduction in price discreteness.

A total of 253 ex-dividend events occurred in the period from March 2005 to December 2006, under the new price discreteness scheme, from which we find that $P D R 1=$ $0.862, P D R 2=0.878$ and $P D R 3=0.911$. We also select 186 cash dividend distribution events in the period from January 2003 to February 2005 as a matched sample, and find that $P D R 1=0.823, P D R 2=0.925$ and $P D R 3=0.968$. Although $P D R 1$ moves closer to 1 , both $P D R 2$ and $P D R 3$ move away from 1. Furthermore, a comparison between the previous price discreteness scheme and the new scheme shows that none of the differences in the $P D R$ measures are statistically significant. ${ }^{12}$

These results therefore provide sufficient evidence to show that our primary results, which reveal significant differences in the $P D R$ measures in the pre-Act period vis-à-vis the post-Act period, are not driven by market-microstructure explanations. Our results are consistent with the findings of Graham et al. (2003), Jakob and Ma (2004) and Cloyd et al. (2006), that market microstructure explanations are not able to fully explain the anomaly of the ex-dividend day price drop.

\subsection{Multivariate Analysis of the Price Drop Ratio}

In order to estimate the relationship between the PDR and the average preference for dividends relative to capital gains, we regress the PDR on several independent variables, as follows: a dummy for the post-Act period (Dummy_Post); stock dividend yield (Dividend Yield); stock return volatility (Volatility); and firm size (Ln_Cap, the logarithm of the

\footnotetext{
${ }^{11}$ For stocks in the price range NT $\$ 15-50$, the price discreteness was reduced from NT $\$ 0.10$ to NT\$0.05, and for stocks in the price range NT $\$ 50-100$, from NT $\$ 0.50$ to NT $\$ 0.10$. Most of our sample stocks fall into the NT\$15-100 price range; therefore, if the market microstructure hypothesis is successful in explaining the PDR, the reduction in price discreteness would have material influences on our PDR measures.

${ }^{12}$ The $t$-statistics for the differences are 1.29 for PDR1, -0.94 for PDR2 and -1.43 for PDR3.
} 
market capitalization). ${ }^{13}$

The regression model is:

$$
\begin{aligned}
\text { PDR } & =\beta_{0}+\beta_{1} \cdot \text { Dummy_Post }+\beta_{2} \cdot \text { Dividend Yield }+\beta_{3} \cdot \text { Volatility } \\
& +\beta_{4} \cdot \text { Ln_Cap }+\varepsilon
\end{aligned}
$$

The dynamic dividend clientele theory predicts that the $P D R$ will be related to the average preference for dividends relative to capital gains, and given that the 1998 Act has increased the average after-tax value of cash dividends, the sign of the coefficient on Dummy_Post is expected to be positive. Similarly, if there is an increase in the PDR with an increase in the average preference for dividends, we could replace the post-Act dummy variable with the average preference for dividends which a firm has $\left(\bar{\alpha}_{i}\right)$.

We set the regression model as:

$$
\begin{aligned}
P D R & =\beta_{0}+\beta_{1} \cdot \bar{\alpha}_{i}+\beta_{2} \cdot \text { Dividend Yield }+\beta_{3} \cdot \text { Volatility } \\
& +\beta_{4} \cdot \text { Ln_cap }+\varepsilon,
\end{aligned}
$$

where the sign of the coefficient on $\bar{\alpha}_{i}$ is also expected to be positive.

As regards the other firm characteristic variables, Elton and Gruber (1970), among others, predict that investors in the high (low) tax brackets tend to hold low (high) dividend paying stocks, implying a positive association between $P D R$ and stock dividend yields (Hypothesis 2). Therefore, the sign on Dividend Yield is again expected to be positive. Michaely and Vila (1995) suggest that the greater the shock on an ex-dividend stock relative to the market risk-bearing capacity on the ex-dividend day, the lower the expected PDR (Hypothesis 3). Thus, we expect to find that the sign on Volatility will be negative. In order to control for the effects of firm size, we include the variable $L n_{-}$Cap (the logarithm of the market capitalization) in the regression models.

\footnotetext{
${ }^{13}$ Since the regression results for $P D R 2$ and $P D R 3$ are qualitatively similar, in order to save space, we only report the $P D R 1$ results in the following analysis; all of the results are, however, available upon request.
} 
The regression results are reported in Table 5. In Model (1), the sign on Dummy_Post is found to be significantly positive $(0.621 ; t$-statistic $=8.35)$, suggesting that ex-day PDR in the post-Act period is significantly higher than in the pre-Act period. In Model (3), when we include three additional independent variables, the coefficient on Dummy_Post is still significantly positive $(0.498 ; t$-statistic $=2.57)$. These results confirm our earlier finding that the 1998 Act materially increases the after-tax value of dividends for investors.

Next, Models (2) and (4) demonstrate that the average tax preference of investors for dividend, $\bar{\alpha}$, successfully explains the variation of ex-day PDR. The coefficient on $\bar{\alpha}$ is significantly positive in both models, indicating that an increase in the average preference of investors for dividends will result in an increase on ex-day PDR. Based on the dynamic clientele dividend model in Michaely and Vila (1995) and our analysis in equation (4), the coefficient of $\bar{\alpha}$ theoretically should be one. In Model (2), the coefficient of $\bar{\alpha}$ is 1.985 , which is higher than one. However, after controlling for firm characteristics, the coefficient of $\bar{\alpha}$ is 1.138 , insignificantly different from one. This result provides direct support for the dynamic dividend clientele, and implying that the average tax preference of all investors for dividends is impounded into the ex-day PDR. This also provides support for our Hypotheses 1a and 1b.

$<$ Table 5 is inserted about here $>$

As for the control variables, the sign on Volatility in Models (3) and (4) is significantly negative, implying that the PDR on the ex-day is smaller for stocks with higher arbitrage risk than for stocks with lower arbitrage risk. This is consistent with the prediction of Michaely and Vila (1995), that greater uncertainties on the ex-day would prevent dividend-capturing trades between tax-advantaged and tax-disadvantaged investors, 
thereby leading to a lower PDR. Similarly, the coefficient on Dividend Yield is found to be positive in Models (3) and (4), with significance in the latter regression $(t$-statistic $=2.87)$, thereby indicating that higher dividend yield stocks are subject to more tax-related trading on the ex-dividend day, moving the PDR closer to 1. Finally, the coefficient of Ln_Cap is found to be significantly negative in both Models (3) and (4).

Overall, the results reported in Table 5 suggest that $P D R$ is increased in the post-Act period, which is consistent with the finding in Zhang et al. (2008). More importantly, we find a positive firm-level association between the PDR and the average tax preference of all investors for dividends, even after control for other factors. In related studies, Michaely and Murgia (1995) examine the association on the market level, and Graham and Kumar (2006) find that the association is significant only for small firms. Our measure for average tax preference of all investors for dividends in a specific firm enables us to explore the association at the firm level. We also find that the PDR is an increasing (decreasing) function of dividend yield (risk). The result is consistent with the findings in Michaely and Murgia (1995) and Zhang et al. (2008), and thereby providing support for our Hypotheses 2 and 3.

\section{Volume around the Ex-Dividend Day}

Although our analysis on price movement on the ex-dividend day does provide information on tax arbitrage trading, it is insufficient to identify the extent of tax-related trading among investors with different tax status. We conduct analysis on volume around the ex-dividend day in this section.

Our earlier discussion suggests that those stocks with a greater degree of tax heterogeneity, and those with higher dividend yields, tend to have higher excess volume 
around the ex-dividend day. By contrast, those stocks associated with high arbitrage risk and those with high transaction costs tend to experience lower volume, essentially because risk and transaction costs discourage the transfer of stocks from investors with dividend tax disadvantages to those with dividend tax advantages. We first present the statistics on excess volume around the ex-dividend day, and then perform multivariate analysis on the excess volume for dividend-paying stocks.

\subsection{Excess Volume around the Ex-dividend Day}

The excess volume of stocks in the eleven days around the ex-dividend day are presented in Table 6, with Panel A reporting the results for the pre-Act period, and Panel B reporting the results for the post-Act period. As Panel A shows, the mean trading volume is just 11 percent higher than the normal trading volume on the cum-dividend day ( $t$-statistic $=1.90)$ and only 8 percent higher than normal on the ex-dividend day $(t$-statistic $=1.46)$. Thus, we can see that in the pre-Act period, for dividend distribution events on either the cum-dividend or ex-dividend day, the average excess trading volume is not significantly different from zero.

$<$ Table 6 is inserted about here $>$

For higher dividend yield stocks, trading gains from the transfer of dividends from investors with tax disadvantages to those with tax advantages will also be higher. It would clearly be of interest to examine the excess volume of high-dividend yield stocks. We evenly divide all of the ex-dividend events in the pre-Act period based upon their dividend yield. The excess volume of the high-dividend yield group is reported in the fourth column of Panel A, which shows that the mean trading volume on the cum-dividend day is 26 percent higher than the normal volume, and is only 5 percent and insignificant on the 
ex-dividend day. Overall, the results suggest that trading volume of dividend paying stocks in the pre-Act period does not materially increase around the ex-dividend day.

Our earlier discussion demonstrates that the implementation of the imputation tax system under the 1998 tax reform dramatically increased tax heterogeneity among investors. Thus, in the post-Act period, we expect to find an increase in excess volume around the ex-dividend day. Panel B of Table 6 confirms this prediction, showing that for the entire dividend distribution events in the post-Act period, the average excess volume is 113 percent on the cum-dividend day $(t$-statistic $=14.97)$ and 67 percent on the ex-dividend day $(t$-statistic $=10.99)$. The fourth column of Panel B also shows that the high-dividend yield sample has even higher average excess volume on both the last cum-dividend day $(176$ percent, $t$-statistic $=14.43)$ and the ex-dividend day $(92$ percent, $t$-statistic $=10.56)$.

These findings demonstrate that excess volume increases with both tax heterogeneity and dividend yield, which is consistent with the idea that the greatest gains from trades among investors with different tax status will be experienced by those stocks with a higher degree of tax heterogeneity and higher dividend yield.

\subsection{Multivariate Analysis of Excess Volume around the Ex-dividend Day}

In order to examine the effects that tax heterogeneity, dividend yield and risk have on excess volume, while also controlling for the influences of other firm characteristics, we conduct a regression analysis of the excess volume on several independent variables; the results are reported in Table 7.

The dependent variable is the average excess volume on both the cum-dividend day and the ex-dividend day for each dividend-paying event $\left(E X V O L_{i}\right)$. The right-hand side regression variables include a dummy for the post-Act period (Dummy_Post), stock 
dividend yield (Dividend Yield), stock return volatility (Volatility), systematic risk (Beta), idiosyncratic risk (Idiosyncratic Risk), firm size (Ln_Cap, the logarithm of the market capitalization) and the illiquidity ratio (Illiquidity) of Amihud (2002).

The analysis in Michaely and Vila (1995) implies that excess volume would have increased in the post-Act period, essentially because the imputation tax system raises the degree of tax heterogeneity. Thus the sign of the coefficient on Dummy_Post is expected to be positive. We also replace Dummy_Post with the tax heterogeneity variable, TAXHET, to directly examine the correlation between excess volume and the degree of tax heterogeneity. A higher value of TAXHET indicates greater gains from tax arbitrage trades which would attract greater market participation around the ex-dividend day. Therefore the sign of the coefficient on TAXHET is also expected to be positive.

As regards the other firm characteristic variables, our earlier discussion suggests that the excess volume around the ex-dividend days should be positively related to the dividend yield and negatively related to the level of transaction costs and risk (as stated in Hypothesis 5). We expect to find that the coefficient on Dividend Yield is positive, and that the coefficients on Volatility and Illiquidity are negative. Michaely and Vila (1996), Michaely et al. (1996) and Dhaliwal and Li (2006) argue that both systematic and idiosyncratic risk will dampen trading activities around the ex-dividend day. In this study, we use two risk measure variables, Beta and Idiosyncratic Risk, to replace Volatility in the right hand side of the regression model and expect to find the ex-day trading volume decreasing in both the Beta and Idiosyncratic Risk.

Only one variable, Dummy_Post, is included as the independent variable in Model (1) of Table 7 , which shows that the coefficient on this variable is significantly positive $(0.805$; 
$t$-statistic $=10.34)$. This dummy variable is then replaced by the tax heterogeneity measure, TAXHET, in Model (2), from which we can see that the coefficient is also significantly positive $(5.243 ; t$-statistic $=7.41)$. Following the inclusion of several control variables in Models (3) to (6), the coefficients on Dummy_Post and TAXHET are still found to be strongly significant. We repeat the regression analyses in Model (6) by using dividend paying sample in the pre- and post-Act periods, respectively. In these two regressions (which are not reported), results are very similar to our baseline results of Table 7 , indicating that our tax heterogeneity variable is very successful in explaining the variation of excess volume around the ex-dividend day. These results are also consistent with the prediction of our Hypothesis 4, that a high degree of tax heterogeneity will induce greater tax arbitrage trading around the ex-dividend day.

\section{$<$ Table 7 is inserted about here $>$}

The other firm characteristic variables included within the regression in Models (3) to (6) also yield similar results. First, all of the coefficients on Dividend Yield in Models (3) to (6) are found to be significantly positive, which suggests that those stocks with higher dividend yields are more likely to attract ex-dividend day trading. Second, both of the coefficients on Volatility in Model (3) and Model (5) are found to be significantly negative, thereby indicating that those stocks with greater uncertainty will tend to discourage investors from engaging in tax arbitrage activities. Third, all of the coefficients on Illiquidity in Models (3) to (6) are found to be negative and marginally significant, and since a high illiquidity ratio indicates high transaction costs, the negative coefficient on Illiquidity implies that those stocks with higher transaction costs will experience less excess trading volume. Finally, firm size seems to play no role in the excess volume 
occurring around the ex-dividend day, since none of the coefficients on Ln_Cap in Models (3) to (6) are found to be significantly different from zero.

As regards our examination of the influences on excess volume arising from systematic and idiosyncratic risks, the coefficients on both Beta and Idiosyncratic Risk, in Models (4) and (6) of Table 7, are found to be significantly negative, consistent with the findings of Michaely and Vila (1996), Michaely et al. (1996) and Dhaliwal and Li (2006), that both systematic risk and idiosyncratic risk will discourage investors from trading around the ex-dividend day.

Overall, the results presented in this section indicate that tax heterogeneity has a significant effect on excess volume around the ex-dividend day, and is consistent with the finding in Dhaliwal and Li (2006), who use (a concave function of) institutional ownership as a proxy for tax heterogeneity. We also demonstrate that when there are higher gains to be made from engaging in tax arbitrage trading (proxied by dividend yield), excess volume will also be significantly higher around the ex-dividend day. Conversely, with an increase in friction (such as risk and transaction costs), there will be a corresponding dramatic reduction in excess volume. These results are generally consistent with the prior research, such as Michaely and Vila (1996), Dhaliwal and Li (2006), and Zhang et al. (2008), and

provide support for Hypothesis 4, that there will be an increase in excess trading volume around the ex-dividend day with tax heterogeneity, and Hypothesis 5, that excess volume around the ex-dividend day will be positively correlated with the dividend yield and negatively correlated with the level of risk and transaction costs.

\section{Trade Imbalance around the Ex-Dividend Day}

Our empirical results reveal excess volume around the ex-dividend day, with this 
excess volume being particularly significant for stocks with high-dividend yields. Our earlier analysis suggests that investors with tax disadvantages relating to dividend receipts would trade with investors who have tax advantages on the dividends received; thus, an analysis of the imbalance on the last cum-dividend day (Day -1) and the ex-dividend (Day 0 ) is of particular interest to our study. Therefore, in this section, we examine the trade imbalance around the ex-dividend day for each category of investors.

Comprehensive and complete transaction records for the 91-day period (centered on the ex-dividend day) were acquired on all of the traders in our 987 ex-dividend events. The dataset comprises of the date and time of the transactions, stock code, buy/sell, trade price and quantity, along with the identity of the traders. The trader code enables us to categorize traders as domestic individual investors, foreign investors, proprietary traders, mutual funds and other corporate investors. Since mutual funds are small, in terms of trading volume, and are subject to the same tax treatment as corporate shareholders, we consign all mutual fund trades to the 'other corporate investors' category.

Proprietary traders are separated from the other corporate shareholders, essentially because Koski and Scruggs (1998) demonstrate that proprietary traders not only have incentives to engage in short-term dividend-capturing trades, but that they also have transaction cost advantages. Given these incentives and advantages, it is of further interest to this study to examine whether proprietary traders will engage in greater tax arbitrage trading than other classes of investors around the ex-dividend day.

Although the dataset is comprehensive and complete, we have no information with regard to the applicable income tax rate for individual investors. Unlike the other classes of investors who are subject to the uniform income tax rate, the individual income tax rate 
ranges from 6 percent to 40 percent; therefore, a complete understanding of the applicable income tax rate is a prerequisite to our trade imbalance analysis. In order to overcome this major drawback of our dataset, we estimate the applicable tax rate for each individual investor identified from the dataset according to their total trade amount.

First, we calculate the total trade value for all investors (including domestic individuals, foreign investors, proprietary traders and other corporate investors) for all of the ex-dividend stocks throughout the 91-day period (centered on the ex-dividend day). Next, for each ex-dividend event, we sort all investors with trade records in this event by their trade value amount. Domestic individual investors whose trade value amount is in the top 10 percent of the trade value amount for all investors are then assigned to the "wealthy individual investors' group, those in the 11 percent to 25 percent range are assigned to the 'medium wealthy individuals' group, and the remaining domestic individuals are classified as 'less wealthy individuals'. This classification divided all of the investors into six categories: 'wealthy individuals', 'medium wealthy individuals', 'less wealthy individuals', 'foreign investors', 'proprietary traders' and 'other corporate investors'.

The buy/sell imbalance of ex-dividend event $i$ for each investor category $k$ on day $t$, $I M B_{i, k, t}$, is calculated as:

$$
I M B_{i, k, t}=\frac{B u y_{i, k, t}-\operatorname{Sell}_{i, k, t}}{B u y_{i, k, t}+\operatorname{Sell}_{i, k, t}}
$$

where $B u y_{i, k, t}\left(\operatorname{Sell}_{i, k, t}\right)$ denotes the dollar volume of buy (sell) trades by investors in event $i$, in group $k$, on day $t$.

Our earlier analyses suggest that due to their dividend tax advantage, less wealthy individuals and corporate shareholders (including proprietary traders and other corporate 
investors) would be net buyers of stocks in the cum-dividend period, while wealthy individuals would be net sellers of stocks prior to the ex-dividend day. Since tax arbitrage trades concentrate on stocks with high-dividend yields, our trade imbalance analysis also focuses on these stocks. Our sample of high-dividend yield events comprises of 176 events in the pre-Act period, and 319 events in the post-Act period. The results are reported in Table 8 .

$<$ Table 8 is inserted about here $>$

The final row (in both Panel A and Panel B of Table 8) reports the average proportion of trades by each investor category over the 91-day period, indicating that individual investors tend to dominate the market around the ex-dividend day, since they account for 76 percent of trading dollar volume in the pre-Act period, and 43 percent in the post-Act period.

When the individuals are classified into the various categories in the pre-Act period, their proportions are wealthy (47 percent), medium wealthy (14 percent) and less wealthy (15 percent), while their respective proportions in the post-Act period are 27 percent, 7 percent and 8 percent. In the pre-Act period, the second largest category is other corporate investors (13 percent), followed by foreign investors (6 percent). Interestingly, the rank is reversed in the post-Act period, where the second largest category is foreign investors (30 percent), followed by other corporate investors ( 25 percent). Clearly, the increased trading proportion of foreign investors underlines the growing importance of these investors within the Taiwan stock market (Huang and Shiu, 2009), while proprietary traders represent a relatively small category, accounting for only about 5 percent of the total trading dollar volume in the pre-Act period, and just 3 percent in the post-Act period. 
Panel A of Table 8 reports the buy-sell imbalance by different classes of investors around the ex-dividend day in the pre-Act period. As the table shows, wealthy individuals tend to sell their shares in the cum-dividend period, prior to the ex-dividend day, where their sell trade dollar volume is found to be 13 percent higher than their buy trade dollar volume on Day -3 (three days prior to the ex-dividend day), and 14 percent higher on both Day -2 and Day -1 ; these traders then reverse to become net buyers on the ex-dividend day. The buy-sell imbalance by wealthy individuals on these days is significantly different from zero. In striking contrast to the wealthy investors, less wealthy individuals, proprietary traders and other corporate investors tend to buy shares in the cum-dividend period while also tending to sell those shares that have gone ex-dividend.

Panel B of Table 8 presents the buy-sell imbalance in the post-Act period. In general, the buy-sell imbalance for each investor group in this period reveals a similar pattern to that in the pre-Act period. Moreover, the buy-sell imbalances are more significant for several investor groups in the post-Act period. The increase in buy-sell imbalances is attributable to the higher degree of tax heterogeneity among investor groups, leading to more tax-induced trades around the ex-dividend day.

Our results in Table 8 suggest that investors who have tax disadvantages (advantages) with regard to their dividend income will sell (buy) shares in the cum-dividend period and buy (sell) shares after the ex-dividend day. This evidence is consistent with prior research, such as Rantapuska (2008) and Felixson and Liljeblom (2008), that different investor groups take opposite oppositions around the ex-day. The result reported in Table 8 provides support the predictions in Hypothesis 6.

\section{Summary and Conclusions}


We set out in this study to investigate the effects of the differential tax rates of investors on price and trading volume around the ex-dividend day by examining the Taiwan stock market, which has no capital gains taxes for all classes of investors and which implemented its imputation tax system in 1998. In the pre-Act period, cash dividends distributed to wealthy individuals were subject to a 40 percent income tax rate, while the respective marginal tax rates for dividends distributed to less wealthy individuals and domestic corporate shareholders were only 6 percent and 5 percent.

Since the imputation tax credits apply only to domestic investors, the after-tax value of dividends for these investors has been raised by the imputation tax system; thus, as a result of the 1998 Act, we would expect to find a higher average preference for dividends relative to capital gains and a higher degree of tax heterogeneity in the post-Act period than in the pre-Act period. Our empirical results, summarized below, provide support for the dynamic dividend clientele model of Michaely and Vila (1995).

An increase is found in the PDR in the post-Act period, and this is clearly associated with the average tax preference of investors for dividends. We find that excess volume is positively correlated with the degree of tax heterogeneity, and thus, is substantially increased in the post-Act period. Furthermore, excess volume is increased when there are high gains to be made from engaging in dividend-capturing trades, and reduced with risk and transaction costs.

Our findings on buy-sell imbalance indicate that wealthy individuals are the most tax-disadvantaged investors, with a tendency to sell shares in the cum-dividend period and buy shares that have gone ex-dividend. In contrast, less wealthy individuals, proprietary traders and corporate shareholders, who have relative tax advantages on dividends, tend to 
buy shares in the cum-dividend period and then sell their shares on the ex-dividend day and thereafter.

Our empirical evidence provides support for the notion that investors will engage in tax arbitrage activities around the ex-dividend day, with such tax arbitrage trading being encouraged by the differentials in the after-tax value of dividends for different investor groups. In conclusion, we demonstrate in this study that the average dividend tax rate of market participants is an important determinant of the ex-day PDR, and that tax-motivated trading activities are the leading cause of excess volume around the ex-dividend day. 


\section{References}

Amihud, Yakov, 2002. Illiquidity and stock returns: cross-section and time-series effects. Journal of Financial Markets 5, 31-56.

Bali, Rakesh, and Gailen L. Hite, 1998. Ex dividend day stock price behavior: discreteness or tax induced clienteles? Journal of Financial Economics 47, 127-159.

Barclay, Michael J., 1987. Dividends, taxes, and common stock prices: The ex-dividend day behavior of common stock prices before the income tax. Journal of Financial Economics 19, 31-44.

Bell, Leonie, and Tim Jenkinson, 2002. New evidence of the impact of dividend taxation and on the identity of the marginal investors. Journal of Finance 57, 1321-1346.

Cloyd, C. Bryan, Oliver Zhen Li, and Connie D. Weaver, 2006. Ticks and tax: The effects of price discreteness and taxation on ex-dividend day returns. Journal of the American Taxation Association 28 (2), 23-46.

Dhaliwal, Dan, and Oliver Z. Li, 2006. Investor tax heterogeneity and ex-dividend day trading volume. Journal of Finance 61, 463-490.

Elton, Edwin J., and Martin J. Gruber, 1970. Marginal stockholder tax rates and the clientele effect. Review of Economics and Statistics 52, 68-74.

Elton, Edwin J., Martin J. Gruber, and Christopher R. Blake, 2005. Marginal stockholder tax effects and ex-dividend-day price behavior: Evidence from taxable versus non-taxable closed-end funds. Review of Economics and Statistics 87, 579-586.

Eades, Kenneth M., Patrick J. Hess, and E. Han Kim, 1984. On interpreting security returns during the ex-dividend period. Journal of Financial Economics 13, 3-34.

Felixson, Karl, and Eva Liljeblom, 2008. Evidence of ex-dividend trading by investor tax category. European Journal of Finance 14, 1-21.

Frank, Murray, and Ravi Jagannathan, 1998. Why do stock prices drop by less than the value of the dividend? Evidence from a country without taxes. Journal of Financial Economics 47, 161-188. 
Graham, John R., and Alok Kumar, 2006. Do dividend clienteles exist? Evidence on dividend preferences of retail investors. Journal of Finance 61, 1305-1336.

Graham, John R., Roni Michaely, and Michael R. Roberts, 2003. Do price discreteness and transactions costs affect stock returns? Comparing ex-dividend pricing before and after decimalization. Journal of Finance 58, 2611-2635.

Hu, Shing-yang, and Yun-lan Tseng, 2006. Who wants to trade around ex-dividend days? Financial Management 35, No.4, 95-115.

Huang, Roger D., and Cheng-Yi Shiu, 2009. Local effects of foreign ownership in an emerging financial market: Evidence from Qualified Foreign Institutional Investors in Taiwan”. Financial Management 38, 567-602.

Jakob, Keith, and Tongshu Ma, 2004. Tick size, NYSE rule 118, and ex-dividend day stock price behavior. Journal of Financial Economics 72, 605-625.

Kalay, Avner, 1982. The ex-dividend day behavior of stock prices: A re-examination of the clientele effect. Journal of Finance 37, 1059-1070.

Karpoff, Jonathan M., and Ralph A. Walkling, 1988. Short-term trading around ex-dividend days: Additional evidence. Journal of Financial Economics 21, 291-298.

Koski, Jennifer Lynch, and John T. Scruggs, 1998. Who trades around the ex-dividend day? Evidence from NYSE audit file data. Financial Management 27 (3), 58-72.

Lakonishok, Josef, and Theo Vermaelen, 1986. Tax-induced tarding around ex-dividend days. Journal of Financial Economics 16, 287-319.

Lasfer, M. Ameziane, 1995. Ex-day behavior: Tax or short-term trading effects. Journal of Finance 50, 875-897.

Lee, Yi-Tsung, Yu-Jane Liu, Richard Roll, and Avanidhar Subrahmanyam, 2006. Taxes and dividend clientele: Evidence from trading and ownership structure. Journal of Banking and Finance 30, 229-246.

Michaely, Roni, and Maurizio Murgia, 1995. The effect of tax heterogeneity on prices and volume around the ex-dividend day: Evidence from the Milan Stock Exchange. Review of Financial Studies 8, 369-399.

Michaely, Roni, and Jean-Luc Vila, 1995. Investors' heterogeneity, price, and volume 
around the ex-dividend day. Journal of Financial and Quantitative Analysis 30, 171-198.

Michaely, Roni, and Jean-Luc Vila, 1996. Trading volume with private valuation: Evidence from the ex-dividend day. Review of Financial Studies 9, 471-509.

Michaely, Roni, Jean-Luc Vila, and Jiang Wang, 1996. A model of trading volume with tax-induced heterogeneous valuation and transaction costs. Journal of Financial Intermediation 5, 340-371.

Poterba, James M., and Lawrence H. Summers, 1984. New evidence that taxes affect the valuation of dividends. Journal of Finance 39, 1397-1415.

Rantapuska, Elias, 2008. Ex-dividend day trading: Who, how, and why? Evidence from the Finnish market. Journal of Financial Economics 88, 355-374.

White, Halbert, 1980. A heteroskedasticity-consistent covariance matrix estimator and a direct test for heteroskedasticity. Econometrica 48, 817-838.

Whitworth, Jeff, and Ramesh P. Rao, 2010. Do tax law changes influence ex-dividend stock price behavior? Evidence from 1926 to 2005. Financial Management 39, 419-445.

Zhang, Yi, Kathleen A. Farrell, and Todd A. Brown, 2008. Ex-dividend day price and volume: The case of 2003 dividend tax cut. National Tax Journal 61, 105-127. 


\section{Table 1 Dividend tax and credits in the pre-and post- 1998 Act periods}

The table presents details on dividend taxation and imputation tax credits in Taiwan. Panel A reports firm-level dividend tax in the pre- and post- 1998 Act periods. The dividend distributed by firms is represented by $D$, with corporate pre-tax earnings being taxed at the rate of $t_{c}$. Panel B reports the investor-level dividend tax and imputation credits in the pre- and post-1998 Act periods. The dividends distributed to domestic individuals are taxed at the personal income tax rate, $t_{d}^{i}$, and the dividends distributed to foreign investors are taxed at the withholding tax rate, $t_{d}^{f}$. Dividend receipts by corporate shareholders had been granted an 80 percent dividend exclusion up to 1998; however, the tax exclusion was subsequently increased to 100 percent. Panel $\mathrm{C}$ report the investor level tax preference for one dollar dividend received in the pre- and post-Act periods

Panel A: Firm-level dividend tax in the pre- and post-1998 Act periods

\begin{tabular}{cccc}
\hline Period & Pre-tax Earnings & Corporate Taxes & Net Income \\
\hline Pre-1998 Act & $\frac{1}{1-t_{c}} \cdot D$ & $\frac{t_{c}}{1-t_{c}} \cdot D$ & $D$ \\
\hline Post-1998 Act & $\frac{1}{1-\mathrm{t}_{\mathrm{c}}} \cdot \mathrm{D}$ & $\frac{\mathrm{t}_{\mathrm{c}}}{1-\mathrm{t}_{\mathrm{c}}} \cdot \mathrm{D}$ & $D$ \\
\hline
\end{tabular}

Panel B: Investor-level dividend tax and credits in the pre- and post-1998 Act periods

\begin{tabular}{|c|c|c|c|}
\hline Variables & $\begin{array}{l}\text { Domestic } \\
\text { Individuals }\end{array}$ & $\begin{array}{l}\text { Domestic } \\
\text { Corporations }\end{array}$ & $\begin{array}{l}\text { Foreign } \\
\text { Investors }\end{array}$ \\
\hline \multicolumn{4}{|l|}{ Pre-1998 Act Period } \\
\hline Dividend Distribution & $D$ & $D$ & $D$ \\
\hline Imputation Tax Credit & - & - & - \\
\hline Taxable Income & $D$ & $D$ & $D$ \\
\hline Income Tax & $t_{d}^{i} \cdot D$ & $0.2 \cdot t_{c} \cdot D$ & $t_{d}^{f} \cdot D$ \\
\hline Investors' After-tax Receipts & $\left(1-t_{d}^{i}\right) D$ & $\left(1-.2 t_{c}\right) D$ & $\left(1-t_{d}^{f}\right) D$ \\
\hline \multicolumn{4}{|l|}{ Post-1998 Act Period } \\
\hline Dividend Distribution & $D$ & $D$ & $D$ \\
\hline Imputation Tax Credit & $\frac{t_{c}}{1-t_{c}} \cdot D$ & $\frac{t_{c}}{1-t_{c}} \cdot D$ & - \\
\hline Taxable Income & $\frac{1}{1-t_{c}} \cdot D$ & $D$ & $D$ \\
\hline Income Tax & $\frac{t_{d}^{i}}{1-t_{c}} \cdot D$ & - & $t_{d}^{f} \cdot D$ \\
\hline Investors' After-tax Receipts & $\frac{1-t_{d}^{i}}{1-t_{c}} \cdot D$ & $D$ & $\left(1-t_{d}^{f}\right) D$ \\
\hline
\end{tabular}


Table 1 (Cont.)

Panel C: Investor level tax preference for one dollar dividend in the pre- and post-Act periods

\begin{tabular}{lcccc}
\hline & $\begin{array}{c}\text { Wealthy } \\
\text { Individuals }\end{array}$ & $\begin{array}{c}\text { Less-wealthy } \\
\text { individuals }\end{array}$ & $\begin{array}{c}\text { Domestic } \\
\text { Corporations }\end{array}$ & $\begin{array}{c}\text { Foreign } \\
\text { Investors }\end{array}$ \\
\hline Marginal tax rate & $40 \%$ & $6 \%$ & $25 \%$ & $20 \%$ \\
\hline $\begin{array}{l}\text { Pre-Act Period } \\
\text { Post-Act Period }\end{array}$ & 0.60 & 0.94 & 0.95 & 0.80 \\
Tax credit $=25 \%$ & 0.80 & 1.2533 & 1 & 0.80 \\
Tax credit $=10 \%$ & 0.6666 & 1.0444 & 1 & 0.80 \\
\hline
\end{tabular}


Table 2 Total number of dividend distributions in the pre- and post-1998 Act periods

The table reports the totals number of dividend distributions for the 1992-2006 sample period, with the pre-Act period including 351 ex-dividend events between 1992 and 1998, and the post-Act period including 636 ex-dividend events between 1999 and 2006. The dividend yield is calculated by dividing the dividend per share by the closing price on the cum-dividend day.

\begin{tabular}{|c|c|c|c|c|c|}
\hline \multirow[t]{2}{*}{ Year } & \multirow{2}{*}{$\begin{array}{l}\text { Total No. of } \\
\text { Dividend } \\
\text { Distributions }\end{array}$} & \multicolumn{2}{|c|}{$\begin{array}{c}\text { Dividend Per Share } \\
\text { (NT\$) }\end{array}$} & \multicolumn{2}{|c|}{$\begin{array}{l}\text { Dividend Yield } \\
(\%)\end{array}$} \\
\hline & & Mean & Median & Mean & Median \\
\hline 1992 & 55 & 1.077 & 1.000 & 2.062 & 1.835 \\
\hline 1993 & 59 & 1.042 & 1.000 & 2.322 & 2.283 \\
\hline 1994 & 58 & 0.921 & 0.800 & 1.745 & 1.488 \\
\hline 1995 & 58 & 0.987 & 1.000 & 2.345 & 2.149 \\
\hline 1996 & 47 & 1.063 & 1.000 & 2.452 & 2.037 \\
\hline 1997 & 40 & 1.036 & 1.000 & 2.062 & 1.898 \\
\hline 1998 & 34 & 0.919 & 1.000 & 2.210 & 1.867 \\
\hline 1999 & 34 & 0.999 & 1.000 & 3.848 & 3.495 \\
\hline 2000 & 42 & 0.931 & 1.000 & 4.517 & 4.217 \\
\hline 2001 & 58 & 1.032 & 0.930 & 7.532 & 7.407 \\
\hline 2002 & 63 & 1.086 & 1.000 & 5.382 & 5.000 \\
\hline 2003 & 94 & 1.156 & 1.000 & 5.400 & 5.208 \\
\hline 2004 & 91 & 1.268 & 1.000 & 5.667 & 5.495 \\
\hline 2005 & 118 & 1.492 & 1.129 & 6.335 & 6.027 \\
\hline 2006 & 136 & 1.535 & 1.023 & 6.038 & 6.004 \\
\hline Pre-Act & 351 & 1.009 & 1.000 & 2.166 & 1.916 \\
\hline Post-Act & 636 & 1.274 & 1.000 & 5.800 & 5.618 \\
\hline Total & 987 & 1.180 & 1.000 & 4.508 & 4.233 \\
\hline
\end{tabular}


Table 3 Descriptive statistics of firm characteristics, ownership, tax preferences and tax heterogeneity

The table presents the descriptive statistics of the dividend distribution events taking place during the 1992-2006 sample period. Panel A reports the descriptive statistics of firm characteristics; Panel B reports the statistics for ownership by various classes of investors for all dividend-paying stocks, where ownership is measured using the data at the end of the sample year; and Panel $\mathrm{C}$ reports the statistics for tax preferences and tax heterogeneity. Market Capitalization is the average market value of the common equity of the dividend-paying firms in the estimation period, defined as $(-45,-6)$ and $(6,45)$; Daily Turnover is the average daily turnover in the estimation period, where turnover is defined as the ratio of shares traded to shares outstanding; Illiquidity Ratio is the Amihud (2002) illiquidity ratio, which is calculated as the ratio of the absolute daily return of the stock to its daily dollar volume, averaged over the estimation period. Volatility is measured by the standard deviation of the daily return of the stock scaled by the standard deviation of the market daily return in the estimation period. Idiosyncratic risk is calculated as the standard deviation of the residuals from the market model scaled by the standard deviation of the market daily return in the estimation period; Beta is calculated from the market model in the estimation period; Alpha $(\bar{\alpha})$ is the tax preference of the average investor on dividends relative to capital gains for the firm in the sample period; and TAXHET is the degree of tax heterogeneity across investors, calculated as the weighted average absolute value of the difference between the tax preference of dividends relative to capital gains and the tax preference of the average investor for a particular class of investors, as defined in Equation (7).

\begin{tabular}{|c|c|c|c|c|c|c|}
\hline Variables & No. & Mean & S.D. & Median & Max. & Min. \\
\hline \multicolumn{7}{|l|}{ Panel A: Firm Characteristics } \\
\hline $\begin{array}{l}\text { Market Capitalization } \\
\text { (NT\$ million) }\end{array}$ & 987 & 33,551 & 73,519 & 7,808 & 595,243 & 290 \\
\hline Daily Turnover (\%) & 987 & 0.637 & 0.806 & 0.350 & 6.431 & 0.012 \\
\hline Illiquidity Ratio (\%) & 987 & 5.200 & 37.869 & 0.610 & $1,121.5$ & 0.008 \\
\hline Volatility & 987 & 1.560 & 0.572 & 1.466 & 4.173 & 0.366 \\
\hline Idiosyncratic Risk & 987 & 1.320 & 0.586 & 1.180 & 4.027 & 0.321 \\
\hline Beta & 987 & 0.743 & 0.354 & 0.752 & 1.819 & -0.400 \\
\hline \multicolumn{7}{|l|}{ Panel B: Ownership } \\
\hline Corporate Shareholders & 934 & 30.975 & 20.331 & 27.010 & 88.630 & 0.090 \\
\hline Foreign Shareholders & 934 & 10.900 & 14.639 & 4.540 & 81.040 & - \\
\hline Individual Shareholders & 934 & 53.616 & 24.004 & 53.305 & 99.910 & 0.020 \\
\hline \multicolumn{7}{|l|}{ Income Tax Rate } \\
\hline $6 \%$ & 934 & 17.059 & 9.187 & 16.222 & 51.747 & 0.013 \\
\hline $13 \%$ & 934 & 11.582 & 5.793 & 11.496 & 30.053 & 0.004 \\
\hline $21 \%$ & 934 & 6.763 & 3.727 & 6.561 & 25.201 & - \\
\hline $30 \%$ & 934 & 4.483 & 3.015 & 3.976 & 28.416 & - \\
\hline $40 \%$ & 934 & 13.730 & 12.231 & 9.926 & 68.384 & - \\
\hline \multicolumn{7}{|c|}{ Panel C: Tax Preferences and Tax Heterogeneity } \\
\hline Alpha $(\bar{\alpha})$ & 934 & 0.930 & 0.100 & 0.909 & 1.385 & 0.670 \\
\hline TAXHET & 934 & 0.148 & 0.082 & 0.127 & 0.538 & 0.018 \\
\hline
\end{tabular}




\section{Table 4 Price drop ratio on ex-dividend days in the pre- and post-1998 Act periods}

The table reports the price drop ratio on ex-dividend days during the 1992-2006 sample period, with the pre-1998 Act period comprising of 351 ex-dividend events from 1992 to 1998, and the post-Act period comprising of 636 ex-dividend events from 1999 to 2006. PDR1 refers to the price drop ratio which is defined as the cum-dividend day closing price minus the ex-dividend day opening price divided by the dividend amount; $P D R 2$ refers to the cum-dividend day closing price minus the ex-dividend day closing price divided by the dividend amount; and PDR 3 refers to the cum-dividend day closing price minus the ex-dividend day closing price (adjusted by the expected return) divided by the dividend amount. The expected return is estimated by the market model in the estimation period, defined as $(-45,-6)$ and $(6,45)$. The t-statistics (z-statistics) report the mean (median) difference test between the post- and pre-1998 Act periods.

\begin{tabular}{|c|c|c|c|c|c|c|c|}
\hline Period & Mean & t-statistic & Std. Dev. & Median & z-statistic & Max. & Min. \\
\hline \multicolumn{8}{|l|}{ Panel A: PDR 1} \\
\hline Pre-1998 Act & 0.247 & - & 1.042 & 0.400 & - & 5.500 & -8.000 \\
\hline Post-1998 Act & 0.868 & - & 1.249 & 0.867 & - & 30.000 & -1.667 \\
\hline Difference: Post-Pre-1998 Act & 0.621 & 7.92 & - & 0.467 & 15.32 & - & - \\
\hline \multicolumn{8}{|l|}{ Panel B: $P D R 2$} \\
\hline Pre-1998 Act & 0.528 & - & 1.492 & 0.733 & - & 7.000 & -7.000 \\
\hline Post-1998 Act & 0.923 & - & 1.350 & 0.944 & - & 30.000 & -5.500 \\
\hline Difference: Post-Pre-1998 Act & 0.395 & 4.24 & - & 0.211 & 5.21 & - & - \\
\hline \multicolumn{8}{|l|}{ Panel C: PDR3 } \\
\hline Pre-1998 Act & 0.507 & - & 1.403 & 0.742 & - & 6.649 & -6.158 \\
\hline Post-1998 Act & 0.955 & - & 1.370 & 0.947 & - & 31.722 & -2.538 \\
\hline Difference: Post-Pre-1998 Act & 0.448 & 4.87 & - & 0.205 & 6.66 & - & - \\
\hline
\end{tabular}




\section{Table 5 Regression analysis results on the price drop ratio}

The table reports the regression results on the price drop ratio (the dependent variable: PDR1) for the 1992-2006 sample period. The price drop ratio is defined as the cum-dividend day closing price minus the ex-dividend day opening price divided by the dividend amount. The Dummy_Post indicator is set as 0 (1) if the dividend distribution is in the pre-Act (post-Act) period. Alpha $(\bar{\alpha})$ is the tax preference of the average investor on dividends relative to capital gains for the firm in the sample period. Dividend Yield is calculated by dividing the dividend per share by the cum-dividend day closing price. Volatility is measured by the standard deviation of the daily return of the stock scaled by the standard deviation of the market daily return in the estimation period. $L n_{-}$Cap is the logarithm of the average market value of the common equity of dividend-paying firms in the estimation period, defined as (-45, -6$)$ and $(6,45)$. The reported t-statistics are White (1980) heteroskedasticity-adjusted t-statistics.

\begin{tabular}{|c|c|c|c|c|c|c|c|c|}
\hline \multirow{3}{*}{ Variables } & \multicolumn{8}{|c|}{ Dependent Variable: $P D R 1$} \\
\hline & \multicolumn{2}{|c|}{ Model (1) } & \multicolumn{2}{|c|}{ Model (2) } & \multicolumn{2}{|c|}{ Model (3) } & \multicolumn{2}{|c|}{ Model (4) } \\
\hline & Coeff. & t-statistic & Coeff. & t-statistic & Coeff. & t-statistic & Coeff. & t-statistic \\
\hline Intercept & 0.247 & 4.44 & -1.190 & -4.25 & 1.211 & 6.43 & 0.260 & 0.59 \\
\hline Dummy_Post & 0.621 & 8.35 & - & - & 0.498 & 2.57 & - & - \\
\hline Alpha $(\bar{\alpha})$ & - & - & 1.985 & 6.64 & - & - & 1.138 & 2.68 \\
\hline Dividend Yield & - & - & - & - & 2.384 & 0.63 & 6.520 & 2.87 \\
\hline Volatility & - & - & - & - & -0.221 & -4.69 & -0.184 & -3.76 \\
\hline Ln_Cap & - & - & - & - & -0.070 & -3.76 & -0.074 & -3.54 \\
\hline Adj- $R^{2}$ & \multicolumn{2}{|c|}{0.059} & \multicolumn{2}{|c|}{0.025} & \multicolumn{2}{|c|}{0.077} & \multicolumn{2}{|c|}{0.061} \\
\hline Total No. of Obs. & \multicolumn{2}{|c|}{987} & \multicolumn{2}{|c|}{934} & \multicolumn{2}{|c|}{987} & \multicolumn{2}{|c|}{934} \\
\hline
\end{tabular}




\section{Table 6 Excess trading volume around ex-dividend days}

The table reports the excess trading volume around ex-dividend days, with Panel A reporting the excess volume for 351 ex-dividend events in the pre-1998 Act period (1992 to 1998), and Panel B reporting the excess volume for 636 ex-dividend events in the post-1998 Act period (1999 to 2006). The excess trading volume is defined as the ratio of the trading volume during the event period $(-5,5)$ over the average daily volume in the estimation period, defined as $(-45,-6)$ and $(6,45)$, minus 1 . The High Dividend Yield Sample in the pre-1998 Act (post-1998 Act) period is defined as those stocks with a dividend yield which is greater than the median in the pre-1998 Act (post-1998 Act) period.

\begin{tabular}{|c|c|c|c|c|}
\hline \multirow{2}{*}{ Trading Day } & \multicolumn{2}{|c|}{ Full Sample } & \multicolumn{2}{|c|}{ High Dividend Yield Sample } \\
\hline & EXVOL $(\%)$ & t-statistic & EXVOL $(\%)$ & t-statistic \\
\hline \multicolumn{5}{|c|}{ Panel A: Excess Volume in the Pre-1998 Act Period } \\
\hline-5 & -2.73 & -0.60 & -5.06 & -0.77 \\
\hline-4 & 2.07 & 0.42 & 2.98 & 0.43 \\
\hline-3 & -19.11 & -4.49 & -20.75 & -3.46 \\
\hline-2 & -17.80 & -4.22 & -14.78 & -2.32 \\
\hline-1 & 11.05 & 1.90 & 25.56 & 2.68 \\
\hline 0 & 8.12 & 1.46 & 5.13 & 0.72 \\
\hline 1 & -2.44 & -0.43 & -2.07 & -0.25 \\
\hline 2 & -4.66 & -1.05 & -4.16 & -0.67 \\
\hline 3 & -8.15 & -1.75 & -4.28 & -0.67 \\
\hline 4 & -4.02 & -0.70 & -3.40 & -0.39 \\
\hline 5 & 1.16 & 0.23 & 1.92 & 0.28 \\
\hline \multicolumn{5}{|c|}{ Panel B: Excess Volume in the Post-1998 Act Period } \\
\hline-5 & 16.03 & 3.27 & 27.47 & 3.42 \\
\hline-4 & 19.75 & 4.22 & 32.99 & 4.44 \\
\hline-3 & 13.09 & 2.51 & 35.34 & 3.85 \\
\hline-2 & 36.88 & 5.80 & 72.63 & 7.00 \\
\hline-1 & 113.27 & 14.97 & 175.78 & 14.43 \\
\hline 0 & 66.99 & 10.99 & 91.65 & 10.56 \\
\hline 1 & 12.23 & 2.50 & 10.15 & 2.12 \\
\hline 2 & -0.21 & -0.05 & 3.19 & 0.53 \\
\hline 3 & -2.18 & -0.57 & -5.94 & -1.22 \\
\hline 4 & -8.69 & -2.37 & -9.74 & -2.34 \\
\hline 5 & -2.53 & -0.59 & -10.87 & -2.39 \\
\hline
\end{tabular}




\section{Table 7 Regression analysis results on excess trading volume, 1992-2006}

The table reports the regression analysis results on excess trading volume during the 1992-2006 sample period. The dependent variable is excess trading volume, which is measured as the average of all cum-dividend day and ex-dividend excess volume. The excess volume is defined as the ratio of the volume in the event period $(-5,5)$ over the average daily volume in the estimation period, defined as $(-45,-6)$ and $(6,45)$. The Dummy_Post indicator is set at $0(1)$ if the dividend distribution is in the pre- (post-) Act period. TAXHET is the degree of tax heterogeneity across investors, which is calculated as the weighted average absolute value of the difference between the dividend tax preferences relative to capital gains of different classes of investors and the tax preference of the average investor as defined in Equation (7). Dividend Yield is calculated by dividing the dividend per share by the cum-dividend day closing price. Volatility is measured by the standard deviation of the stock daily return scaled by the standard deviation of the market daily return in the estimation period. Beta is calculated from the market model in the estimation period. Idiosyncratic Risk is calculated as the standard deviation of the residuals from the market model scaled by the standard deviation of the market daily return in the estimation period. $L n_{-} C a p$ is the logarithm of the average market value of the common equity of dividend-paying firms in the estimation period, which is defined as the periods $(-45,-6)$ and $(6,45)$. Illiquidity is the Amihud (2002) illiquidity ratio, which is calculated as the ratio of the absolute daily return of the stock to its daily dollar volume, and then averaged over the estimation period. The reported t-statistics are White (1980) heteroskedasticity-adjusted t-statistics.

\begin{tabular}{|c|c|c|c|c|c|c|c|c|c|c|c|c|}
\hline \multirow{3}{*}{ Variables } & \multicolumn{12}{|c|}{ Dependent Variable: Excess Trading Volume } \\
\hline & \multicolumn{2}{|c|}{ Model (1) } & \multicolumn{2}{|c|}{ Model (2) } & \multicolumn{2}{|c|}{ Model (3) } & \multicolumn{2}{|c|}{ Model (4) } & \multicolumn{2}{|c|}{ Model (5) } & \multicolumn{2}{|c|}{ Model (6) } \\
\hline & Coeff. & t-stat. & Coeff. & t-stat. & Coeff. & t-stat. & Coeff. & t-stat. & Coeff. & t-stat. & Coeff. & t-stat. \\
\hline Intercept & 0.096 & 2.01 & -0.144 & -1.47 & 0.778 & 1.68 & 0.693 & 1.50 & -0.038 & -0.08 & -0.036 & -0.08 \\
\hline Dummy_Post & 0.805 & 10.34 & - & - & 0.309 & 3.08 & 0.264 & 2.66 & - & - & - & - \\
\hline TAXHET & - & - & 5.243 & 7.41 & - & - & - & - & 3.378 & 4.78 & 3.013 & 4.22 \\
\hline Dividend Yield & - & - & - & - & 14.893 & 5.81 & 14.318 & 5.63 & 15.964 & 7.12 & 15.381 & 7.03 \\
\hline Volatility & - & - & - & - & -0.503 & -6.67 & - & - & -0.445 & -6.14 & - & - \\
\hline Beta & - & - & - & - & - & - & -0.721 & -5.84 & - & - & -0.635 & -4.94 \\
\hline Idiosyncratic Risk & - & - & - & - & - & - & -0.336 & -4.50 & - & - & -0.306 & -4.19 \\
\hline Ln_Cap & - & - & - & - & -0.026 & -0.68 & 0.010 & 0.24 & 0.015 & 0.38 & 0.043 & 1.00 \\
\hline Illiquidity & - & - & - & - & -0.001 & -1.97 & -0.001 & -1.95 & -0.001 & -1.82 & -0.001 & -1.81 \\
\hline $\operatorname{Adj}-R^{2}$ & \multicolumn{2}{|c|}{0.074} & \multicolumn{2}{|c|}{0.089} & \multicolumn{2}{|c|}{0.170} & \multicolumn{2}{|c|}{0.183} & \multicolumn{2}{|c|}{0.196} & \multicolumn{2}{|c|}{0.206} \\
\hline Total No. of Obs. & \multicolumn{2}{|c|}{987} & \multicolumn{2}{|c|}{934} & \multicolumn{2}{|c|}{987} & \multicolumn{2}{|c|}{987} & \multicolumn{2}{|c|}{934} & \multicolumn{2}{|c|}{934} \\
\hline
\end{tabular}




\section{Table 8 Trading volume and buy-sell imbalance around ex-dividend days, by investor classes}

The table reports the trading volume and buy-sell imbalance around ex-dividend days for different classes of investors, with the sample period running from 1992 to 2006. Investors are classified as 'wealthy individuals', 'medium wealthy individuals', 'less wealthy individuals', 'foreign investors', 'proprietary traders' and 'other corporate investors'. Panel A reports the high-dividend yield stocks in the pre-Act period ( $\mathrm{N}=176)$, and Panel B reports the high-dividend stocks in the post-Act period $(\mathrm{N}=319)$. The buy-sell imbalance (Imbalance) is defined as (buy dollar volume - sell dollar volume) / (buy dollar volume + sell dollar volume) by a particular investor category; Weight refers to the weight of trading volume by each category of investors, calculated as the average of all buys and sells by a particular investor category divided by the total trading volume. The reported t-statistics refer to the null hypothesis $\left(H_{0}\right.$ : Imbalance $\left.=0\right)$.

\begin{tabular}{|c|c|c|c|c|c|c|c|c|c|c|c|c|}
\hline \multirow{2}{*}{$\begin{array}{l}\text { Trading } \\
\text { Day }\end{array}$} & \multicolumn{2}{|c|}{ Wealthy Individuals } & \multicolumn{2}{|c|}{$\begin{array}{l}\text { Medium wealthy } \\
\text { Individuals }\end{array}$} & \multicolumn{2}{|c|}{$\begin{array}{l}\text { Less wealthy } \\
\text { Individuals }\end{array}$} & \multicolumn{2}{|c|}{ Foreign Investors } & \multicolumn{2}{|c|}{$\begin{array}{l}\text { Proprietary } \\
\text { Investors }\end{array}$} & \multicolumn{2}{|c|}{$\begin{array}{l}\text { Other Corporate } \\
\text { Investors }\end{array}$} \\
\hline & Imbalance & t-statistic & Imbalance & t-statistic & Imbalance & t-statistic & Imbalance & t-statistic & Imbalance & t-statistic & Imbalance & t-statistic \\
\hline \multicolumn{13}{|l|}{ Panel A: } \\
\hline-3 & -0.13 & -6.59 & -0.03 & -1.14 & 0.07 & 3.30 & 0.20 & 1.38 & 0.49 & 4.08 & 0.15 & 2.32 \\
\hline-2 & -0.14 & -7.17 & 0.01 & 0.46 & 0.09 & 3.96 & 0.47 & 4.01 & 0.26 & 1.99 & 0.22 & 3.70 \\
\hline-1 & -0.14 & -8.36 & 0.02 & 1.10 & 0.08 & 4.13 & 0.27 & 2.09 & 0.20 & 1.60 & 0.27 & 4.44 \\
\hline 0 & 0.04 & 2.57 & -0.07 & -3.91 & -0.03 & -1.69 & 0.03 & 0.23 & -0.40 & -3.25 & -0.09 & -1.41 \\
\hline 1 & 0.01 & 0.46 & -0.05 & -2.39 & -0.05 & -2.43 & 0.09 & 0.55 & -0.28 & -2.18 & 0.07 & 1.10 \\
\hline 2 & -0.03 & -1.66 & -0.08 & -3.31 & -0.09 & -4.57 & 0.15 & 1.03 & 0.12 & 0.90 & 0.17 & 2.68 \\
\hline 3 & 0.00 & 0.29 & -0.08 & -3.42 & -0.09 & -4.41 & -0.07 & -0.53 & 0.01 & 0.07 & 0.10 & 1.47 \\
\hline Weight & \multicolumn{2}{|c|}{0.475} & \multicolumn{2}{|c|}{0.143} & \multicolumn{2}{|c|}{0.145} & \multicolumn{2}{|c|}{0.061} & \multicolumn{2}{|c|}{0.045} & \multicolumn{2}{|c|}{0.133} \\
\hline \multicolumn{13}{|l|}{ Panel B: } \\
\hline-3 & -0.13 & -7.29 & 0.07 & 3.18 & 0.09 & 4.38 & 0.08 & 1.17 & -0.02 & -0.26 & 0.14 & 2.79 \\
\hline-2 & -0.17 & -10.26 & 0.14 & 7.19 & 0.15 & 7.79 & 0.13 & 2.01 & 0.11 & 1.62 & 0.28 & 5.67 \\
\hline-1 & -0.22 & -16.01 & 0.12 & 7.08 & 0.19 & 11.88 & 0.19 & 2.94 & 0.40 & 6.84 & 0.23 & 4.84 \\
\hline 0 & 0.10 & 6.43 & -0.11 & -6.16 & -0.02 & -1.04 & 0.00 & -0.07 & -0.22 & -3.42 & -0.21 & -3.81 \\
\hline 1 & 0.05 & 3.02 & -0.10 & -4.33 & -0.03 & -1.67 & -0.01 & -0.12 & -0.03 & -0.41 & -0.01 & -0.11 \\
\hline 2 & 0.03 & 1.63 & -0.11 & -4.95 & -0.06 & -3.09 & 0.03 & 0.40 & -0.04 & -0.53 & 0.07 & 1.20 \\
\hline 3 & 0.04 & 2.29 & -0.11 & -4.91 & -0.07 & -3.79 & 0.12 & 1.69 & -0.05 & -0.79 & -0.01 & -0.10 \\
\hline Weight & \multicolumn{2}{|c|}{0.269} & \multicolumn{2}{|c|}{0.075} & \multicolumn{2}{|c|}{0.081} & \multicolumn{2}{|c|}{0.302} & \multicolumn{2}{|c|}{0.027} & \multicolumn{2}{|c|}{0.246} \\
\hline
\end{tabular}

